\title{
THINKING LIKE A LAWYER ABOUT LEGISLATION: IMPLEMENTING LEGISLATIVE DECISION THEORY THROUGH IMPROVED CITATION
}

\author{
Hugh L. Brady ${ }^{*}$
}

The Texas Supreme Court in the late 1990s, in two significant cases, arguably interpreted statutes to achieve a result directly opposite to the Texas Legislature's decision to adopt a specific text. Why do lawyers and judges struggle when reading and applying legislation, especially when using enactment history? Under Professor Victoria Nourse's legislative decision theory, the struggle is attributable to the fact that lawyers do not consider the legislature's institutional rules and procedures to find the proper text to interpret a statute in light of the available legislative evidence. Wider implementation of her theory is hampered by current legal citation practices that mistreat legislative evidence and legislation itself and inhibit legal reasoning when using these authorities. The Bluebook and other citation manuals are designed primarily to enable sophisticated reasoning with case law. This bias is demonstrated by the ways in which the Bluebook has radically altered how lawyers and judges think about federal law with little notice. Legislative decision theory shows how accepted legislative procedures indicate the Texas Supreme Court reached the opposite result decided by the Legislature in each case. Because current legal citation practice did not provide a method for citing the proper legislative action, the court was unable to read the pertinent statutes in light of the relevant legislative evidence. Using Texas as a case study, a detailed review of the legislative process and the legislative evidence it produces demonstrates the need for comprehensive and workable citation practices for legislation. These goals are best achieved by individual states' issuance of a specialized citation manual, such as a proposed Orangebook for Texas, to prevent recurring, substantial errors made by lawyers and courts in interpreting statutes.

\footnotetext{
* Senior Lecturer in Law, The University of Texas School of Law; Parliamentarian, Texas House of Representatives. The views presented in this Article are solely mine and do not represent the views of the Texas House of Representatives.

I wish to thank Bryan A. Garner, James Hambleton, Tobias A. Dorsey, and Judge Amy Clark Meachum (among others), for their keen review of, and comments on, prior drafts.
} 
INTRODUCTION.

Contents

I. BetTer ThinKING ABOUT LEGISLATION—AND WHY WE HAVEN'T BEEN DOING IT ALREADY

A. Better Thinking About Legislation: Legislative Decision THEORY

B. Why We HaVEN'T BeEN DOING IT AlREADY: LEGAL CitATION AS AN OBSTACLE TO WIDER IMPLEMENTATION OF LEGISLATIVE DECISION THEORY.

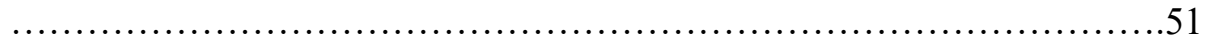

1. Legal Citation as Legal Thought ......................................................53

2. Legal Citation is Designed for Common-Law Thought .......................55

3. How Legal Citation Has Hindered Thinking About Legislation .........58

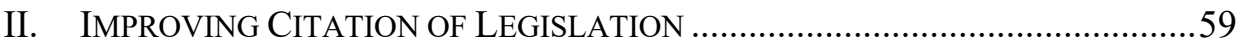

A. ApPlying Legislative DeCiSION THEORY to JONES AND FLEMING

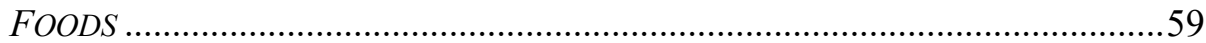

B. How Legal Citation Mistreats Legislative Evidence: A State-

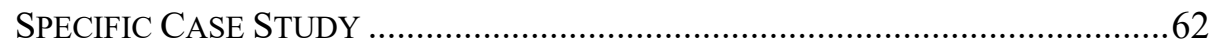

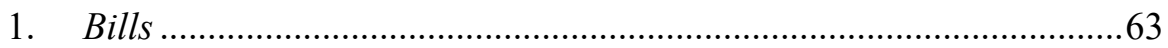

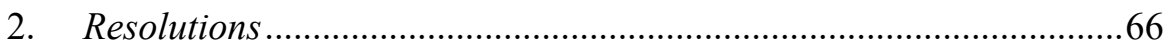

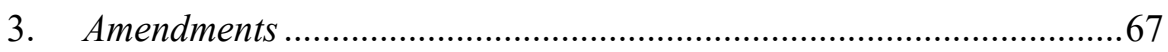

4. Procedural History and Explanatory Notations ..................................68

III. THE WAY FORWARD: CITATION MANUALS FOR LEGISLATION ..............70

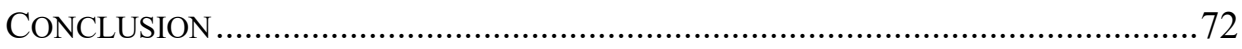

APPENDIX A: TOPIC OUTLINE For LEGISLATIVE CitATION MANUALS .............73

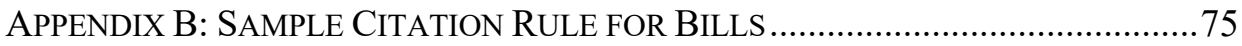




\section{INTRODUCTION $^{1}$}

In a pair of cases in the late 1990s, the Supreme Court of Texas considered a somewhat obscure, yet important question: What should courts do when the legislature enacts a non-substantive codification of the laws on a given subject, yet the "clear, unambiguous statutes that were drafted... as part of the codification process" make a "substantive departure from [the] prior law[?]"2 Should the courts disregard the mistake made during the codification process and apply the prior law and its interpretation? ${ }^{3}$ Or should the courts apply the current law on its terms to effect the substantive change? ${ }^{4}$

In both cases, the codifications were characterized as non-substantive revisions of the law that were not intended by the Texas Legislature ${ }^{5}$ to "alter the sense, meaning, or effect of the statute." action under the Texas Family Code in which two same-sex partners were fighting over visitation rights to a child the couple raised together for about three years from the child's birth. ${ }^{7}$ The second case, Fleming Foods of Texas, Inc. v. Rylander, was an action brought under the Texas Tax Code by a corporation seeking a refund of sales taxes it paid through a third party without first obtaining a statutorily required assignment of the refund right. ${ }^{8}$

In answering the questions posed at the beginning of this Article, the court gave two different answers based on its independent determination of whether the codifications' changes in restating the law were, in fact, non-substantive. In Jones, it held that the Family Code codification's change was non-substantive and denied visitation rights to the plaintiff. ${ }^{9}$ In Fleming Foods, it held that the Tax Code codification's change was substantive and permitted the corporation to obtain a tax refund of at least $\$ 350,000 .^{10}$

In both cases, the court's use of statutory enactment history was criticized. In Jones, "the court's rationale for considering legislative intent lack[ed] something

\footnotetext{
${ }^{1}$ Citations in footnotes are generally prepared according to THE BLUEBOOK: A UNIFORM SYSTEM OF Citation (Columbia L. Rev. Ass'n et al. eds., 20th ed. 2015) [hereinafter BLUEBOOK 20th ed.]. Citations to Texas-specific sources, other than the suggested forms in Part II, are generally prepared according to TEXAS Rules OF FORM: THE GREENBOOK (Texas L. Rev. ed., 14th ed. 2018) [hereinafter GREENBOOK 14th ed.]. For prior editions, these short forms are used after a full reference, e.g., GREENBOOK 13th ed. I use "the Bluebook" and "the Greenbook" for simplicity's sake. Finally, I use only the archive URL for Internet sources to spare future readers from frustration associated with clicking dead links. See Henry A. Feild, James Allan \& Rosie Jones, Predicting Searcher Frustration, Address Before the 33rd Annual International ACM SIGIR Conference (July 2010), in ProceEdings of THE 33RD ANNUAL InTERNATIONAL ACM SIGIR CONFERENCE, 2010, at 34, 37.

${ }^{2}$ Fleming Foods of Tex., Inc. v. Rylander, 6 S.W.3d 278, 283 (Tex. 1999).

${ }^{3}$ See Stephanie M. Dooley, The Select Committee on Judicial Interpretations, 14 APP. ADVOC. 7 (2001).

${ }^{4}$ See Ron Beal, The Art of Statutory Construction: Texas Style, 64 BAYLOR L. REV. 339, 357-58 (2012).

${ }^{5}$ The Texas Legislature will be referred to as "the Legislature" throughout this article.

${ }^{6}$ TEX. GOV'T CODE ANN. $\S 323.007$ (b) (West, Westlaw through the end of the 2019 Regular Session of the 86th Legislature).

${ }^{7}$ Jones v. Fowler, 969 S.W.2d 429, 430 (Tex. 1998).

${ }^{8}$ Fleming Foods, 6 S.W.3d at 279.

${ }^{9}$ Jones, 969 S.W.2d at 433.

${ }^{10}$ Fleming Foods, 6 S.W.3d at 286.
} 
in lucidity."11 In response to Fleming Foods, the Speaker of the Texas House of Representatives created a select committee for reviewing appellate decisions "to identify those decisions that ... clearly failed to properly implement legislative purposes." 12

Lawyers ${ }^{13}$ are uncomfortable with the statute book. ${ }^{14}$ We struggle with legislation, ${ }^{15}$ as in Jones and Fleming Foods, because we do not understand the legislative process that produces it. ${ }^{16}$ This may be surprising as we live in an age of statutes, where legislation shapes and controls wide swaths, if not the near-entirety, of modern law. ${ }^{17}$ In such an age, "competent lawyers must understand not just what the law is but also how law gets made."18

One good reason for our inexpert use of statutes is that legal education does not prepare us to think about legislation in the same way it prepares us to think about the common law because it does not provide us the necessary "general skills of dealing with legislatures and their statutory products" 19 in the same manner as case

11 James W. Paulsen, Family Law: Parent and Child, 52 SMU L. REV. 1197, 1203 (1999). Professor Paulsen thought Jones was "probably legally correct." Id. This was in part because it "relied on clear legislative history that no substantive change was intended." Id. at 1202. As we shall see in Part II, the enactment history supports the opposite conclusion concerning whether the Legislature decided that it was making some substantive change in the Family Code codification.

12 TEX. HOUSE OF REPRESENTATIVES SELECT COMM. ON JUD. INTERPRETATIONS OF L., INTERIM REPORT TO THE 77TH TEXAS LEGISLATURE ii (2000).

${ }^{13}$ For readability, I use the term "lawyers" to include judges when discussing the legal profession.

14 Tobias A. Dorsey, Some Reflections on Yates and the Statutes We Threw Away, 18 GREEN BAG 2D 377, 377-78 (2015).

15 Strictly speaking, "legislation" means only the basic sources of written, positive law adopted through a formal process focused on production of a final text that is governed by both political and legal norms, including final approval by representative actors. See, e.g., Jeremy Waldron, The Dignity of Legislation, 54 MD. L. REV. 633, 659-60, 661-65 (1995); Legislation, BLACK'S LAW DICTIONARY (10th ed. 2014). However, "[1] egislation is mostly about process[:] . . . the process through which courts and administrative agencies interpret statutes . . . [and] the process through which statutes are enacted into law." Dakota S. Rudesill, Christopher J. Walker \& Daniel P. Tokaji, A Program in Legislation, 65 J. LEG. EduC. 70, 79 (2015). Thus, I use the term to refer to both statutes and the materials associated with the process that evidence the final text's enactment.

${ }^{16}$ See infra Part I.A.

${ }^{17}$ Guido CAlabresi, A COMmon LAw FOR the AgE OF StATUTEs 1 (1982) (describing the "fundamental change in American law" during the twentieth century from "a legal system dominated by the common law, divined by courts, to one in which statutes, enacted by legislatures, have become the primary source of law"); Elizabeth Garrett, Teaching Law and Politics, 7 N.Y.U. J. LEGIS. \& PUB. POL'Y 11, 14 (2003) ("We live in an age of statutes ....").

${ }^{18}$ Rudesill, Walker \& Tokaji, supra note 15 , at 79.

${ }^{19}$ William N. Eskridge, Jr. \& Philip P. Frickey, Legislation Scholarship and Pedagogy in the Post-Legal Process Era, 48 U. PITT. L. REV. 691, 691 (1987); see also Robert F. Williams, Statutory Law in Legal Education: Still Second Class After All These Years, 35 MERCER L. REV. 803, 832-38 (1984). In 2015, just five of the top ninety-nine law schools (as ranked in 2014 by U.S. News and World Report) required students to take a legislation course as part of their graduation requirements. Abbe R. Gluck, The Ripple Effect of "Leg-Reg" on the Study of Legislation \& Administrative Law in the Law School Classroom, 65 J. LEG. EDUC. 121, 124, 126-27 (2015). Seventeen required students to complete a "legislation-regulation" course as part of their graduation requirements. Id. at 127-28. These courses treat "legislation" as statutory interpretation from the judicial perspective and have a strong administrative law component. See id. at 156-57 (noting, in discussing the content of "leg-reg" syllabi, that "the legislation topics covered are fairly constant[:] the main canons of construction, legislative history, and the central theories of interpretation.... [A] number of upper-level legislation courses at schools without required courses do cover a range of more advanced topics, including complexities of the legislative process. ... These generally do not appear in the leg-reg syllabi ....”). 
law. Legal theories of statutory interpretation view the legislative process with a jaundiced eye. ${ }^{20}$ Professor Victoria Nourse's legislative decision theory has recently emerged to challenge this stance with its insistence that statutory interpretation must consider the legislature's institutional rules and procedures to find the proper text to interpret in light of the available legislative evidence. ${ }^{21}$ However, wider use of legislative decision theory is hindered by our lack of ability to deftly use the evidence of a statute's enactment to construct and support legal arguments for the conclusive reading of a statutory text. ${ }^{22}$ We lack this skill in part because legal citation does not provide us the same tools to expertly describe the authoritative nature of legislation as it does for cases.

We build our legal arguments using "the language of authority," which includes the "conventions of legal citation." 23 Citation to authority, whether cases or statutes, is a fundamental component of common-law systems and their methods of reasoning. ${ }^{24}$ However, "[l]egal sophisticates these days worry little about the ins and outs of citation, tending instead to cast their lot with the legal realists in believing that the citation of legal authorities . . . is scarcely more than a decoration." ${ }^{25}$ This view overlooks "the point that citation practice is intimately connected with the authoritative core of the idea of law." 26 Legal citation is indispensable to legal argument because it is the method we use to "characterize and use law" and forms "the basis of virtually all legal conversation in a common law system." 27 Reflecting the case-centric nature of the common-law system, ${ }^{28}$ the Bluebook-and by extension, legal citation - does not treat legislation with the same care as it does cases. This hinders us from appropriately characterizing and using legislation. ${ }^{29}$

That legal citation is partly responsible for our inexpert use of legislation seems surprising only to those who view it as a matter of style. But it is precisely because the "rules of citation are ... guides to argumentation ... and the form of citation conveys (or argues for) the strength of an authority" that legal citation of legislation deserves critical examination and "substantive analysis of the ways that lawyers use authority." 30

In Part I, I outline Nourse's legislative decision theory and its insistence that, unlike the other major theories, statutory interpretation must consider the legislature's

\footnotetext{
${ }^{20}$ See infra Part I.A.

${ }^{21}$ See generally ViCTORIA NOURSE, MisREAdING LAW, MisREADING DEMOCRACY (2016) [hereinafter NOURSE, MiSREADING LAW].

${ }^{22}$ See Kris Franklin, “. . . See Erie. ”: Critical Study of Legal Authority, 31 U. ARK. LiTTLE Rock L. REV. 109, 111 (2008).

${ }^{23}$ FrEDERICK SCHAUER, THINKING LIKE A LAWYER: A NEW INTRODUCTION TO LEGAL REASONING 6667, 73 (2009) [hereinafter SCHAUER, THINKING LIKE A LAWYER].

${ }^{24}$ Byron D. Cooper, Anglo-American Legal Citation: Historical Development and Library Implications, 75 L. LiBR. J. 3, 7, 9-17 (1982); Peter M. Tiersma, The Textualization of Precedent, 82 NoTRE DAME L. REV. 1187, 1193-96 (2007).

${ }^{25}$ Frederick Schauer, Authority and Authorities, 94 VA. L. REV. 1931, 1932 (2008).

${ }^{26} \mathrm{Id}$. at $1934-35$.

${ }^{27}$ Franklin, supra note 22, at 111.

${ }^{28}$ See infra Part I.B.

${ }^{29}$ This is true regardless of the theory of statutory interpretation one subscribes to.

${ }^{30}$ Franklin, supra note 22 , at $111-12$.
} 
institutional rules and procedures to find the proper text to interpret in light of the available legislative evidence that provides necessary context to understand what the legislature decided. I then investigate how current legal citation presents an obstacle to the wider implementation of Nourse's theory because it reinforces common-law patterns. This view is supported by the history of the Bluebook's development as a manual of common-law thought and how it has, without notice or uproar, significantly and detrimentally altered the way lawyers think about federal statute law.

I return back to Jones and Fleming Foods in Part II and apply legislative decision theory to show how accepted legislative procedures indicate the Supreme Court of Texas reached the opposite result decided by the Texas Legislature in each case. I also show that the court was unable to read the codification bills in light of the relevant legislative context because Texas legal citation practice did not provide a method for citing the proper legislative action. Using the Texas Legislature as a case study, I then evaluate how Texas legal citation practice mishandles Texas legislation in order to outline areas for improvement.

In Part III, I discuss the need for sustained effort to develop robust citation practices for legislation that will support its more expert use by lawyers and sketch the broad outlines of, and goals to be achieved by, specialized citation manuals for legislation. Lawyers have difficulty when dealing with legislation because citation practices for legislative authorities are woefully undeveloped and inadequate. Developing legal citation rules to address the special problems presented by legislation should help improve the interpretation and application of statutes by aiding their sophisticated reasoning by lawyers. Finally, two appendixes outline topics to be included in a citation manual for legislation. The appendixes also set out a citation rule for bills, providing an example of legal citation practices for bills that permit expert implementation of legislative decision theory.

This Article makes small, but meaningful, contributions to the ongoing debates over statutory interpretation. Its examination of Jones and Fleming Foods provides additional, compelling proof of Nourse's legislative decision theory. ${ }^{31}$ Just as importantly, it does so in the context of the state legislative process, where it has been presumed that "a different approach to statutory interpretation is needed" in states where legislative evidence is scarce. ${ }^{32}$ This Article shows that legislative decision theory's methodology overcomes this presumption and works both nationally and sub-nationally because it uses each legislature's specific modes of procedure $^{33}$ This Article also illustrates how legal citation practice substantially

\footnotetext{
${ }^{31}$ See James E. Pfander, Statutory Interpretation for Courts and Lawyers, JoTweLL (Mar. 26, 2018), https://perma.cc/F5QQ-YBEB (reviewing NOURSE, MISREADING LAW, supra note 21).

${ }^{32}$ Richard A. Briffault, Beyond Congress: The Study of State and Local Legislatures, 7 N.Y.U. J. LEGIS. \& PUB. POL'Y 23, 24 (2003) ("'W]ith Congress, the fifty states, and thousands of county and municipal legislatures to consider, a comprehensive analysis is well beyond my individual capacity.").

${ }^{33}$ For example, these additional proofs could provide grounds for reconsidering, in light of legislative decision theory's ability to scale, the normative prescriptions of the "growing literature on whether lower federal courts and state courts should do statutory interpretation differently." Aaron-Andrew P. Bruhl, Statutory Interpretation and the Rest of the Iceberg: Divergences Between the Lower Federal Courts and the Supreme Court, 68 DUKE L.J. 1, 7 (2018) (collecting articles that argue for, among other things, statutory interpretation approaches dependent on: a court's institutional capacity; its place in the judicial hierarchy; whether its judges
} 
mishandles legislation, evidences the need for better legal citation of legislation regardless of one's theoretical approach to statutory interpretation, and proffers an approach to developing specialized citation manuals to meet this need.

\section{Better Thinking About Legislation-AND Why We HaVen'T BEEN DOING IT ALREADY}

In this Part, I give a highly abbreviated account of the legislative decision theory advanced by Professor Victoria Nourse, ${ }^{34}$ including some obstacles to practical application of the legislative decision theory by lawyers. Having considered how legal citation helps lawyers and judges think about case law, I also consider in this Part how legal citation does not help them think about legislation because legal citation as expressed by the common-law manuals does not require all significant information to provide the necessary contextual evidence of a statute's enactment.

\section{A. Better Thinking About Legislation: Legislative Decision Theory}

"[L]egislation is the primary instrument of ordered social change . . .".35 And, "[i]n ordinary usage and in the daily work of most lawyers, there is no question[:] Legislation is law . . . [and] it constitutes the bulk of the legal materials that ordinary people have to come to terms with." ${ }^{36}$ Legislation must be discussed and considered in legislative chambers, executive offices, agency headquarters, and law offices. Yet, even in the simplest of cases - those that do not present any particular tension between competing theories of statutory interpretation-lawyers commit basic errors when reading legislation. ${ }^{37}$ Why?

The answer is that lawyers, by training, view the legislative process through a judicial lens. This is attributable to the fact that "[m]ore than occasionally, law professors reveal a stunning lack of knowledge about [the] Congress's rules." 38 This lack of knowledge "reflects the failure of the standard law school curriculum," ${ }^{39}$ most particularly its reliance on the case method, which teaches facility with judicial, rather

are elected or appointed; and whether they possess general common-law powers not available to federal courts).

${ }^{34}$ Which, of course, does not accord it the full justice to which it is entitled.

${ }^{35}$ Joseph Dolan, Law School Teaching of Legislation - A Report to the Ford Foundation, 22 J. LEG. EDUC. 63, 63 (1969).

${ }^{36}$ JeREMy WALDRON, THE Dignity OF Legislation 11 (1999).

${ }^{37}$ William J. Aceves, Correcting an Evident Error: A Plea to Revise Jesner v. Arab Bank, PLC, 107 GeO. L.J. ONLINE 63, 64-65, 70-77 (2018) (explaining how Justice Anthony Kennedy, in looking for "analogous statutes for guidance" when considering the scope of common-law actions, misread the significance of placing one congressional act as a statutory note to another, and thus "disregarded long-standing practice and black letter law that the placement of a statutory note ... does not have any substantive impact on the law's meaning, interpretation, or application" (internal quotation marks omitted)).

${ }^{38}$ Victoria F. Nourse, A Decision Theory of Statutory Interpretation: Legislative History by the Rules, 122 YALE L.J. 70, 72 (2012) [hereinafter Nourse, Decision Theory].

${ }^{39} I d$. 
than legislative, texts and thought. ${ }^{40}$ As Elizabeth Garrett explained:

[B]ecause of the traditional first-year [law school] curriculum and the way we talk as lawyers, we think that what we're doing is primarily common law. That perception is simply wrong.... course[s] in regulatory and legislative processes explicitly reveal[] the dominance of statutes and regulations over common law. ${ }^{41}$

Lawyers' common-law bias is why, as Nourse explains, the main competing theories of statutory interpretation - textualism, purposivism, and positive political theory ${ }^{42}$ - are not grounded in any positive view of the legislative process ${ }^{43}$ including the legislature's predetermined rules for making decisions to enact (or not enact) legislation. ${ }^{44}$ Coupled with their focus on the elusiveness of discerning legislative intent as a mental state revealed by legislative history, standard statutory interpretation theories seriously taint the work of lawyers seeking to implement statutory law and lead them to substantial error. ${ }^{45}$

Common-law bias also explains why the main theories all "impose legalistic visions of how courts and judges operate onto a very different institution central to our democracy." ${ }^{46}$ These visions are divorced from a realistic vision of legislatures ${ }^{47}$ as institutions where members are subject to regular elections, which requires them to generally anticipate and vote for what their constituents want - what Nourse terms the "electoral connection." 48 Legislation must overcome significant procedural obstacles before it is presented to the executive for approval. Among these obstacles in the Congress is the likelihood of a filibuster in the Senate. ${ }^{49}$ Ending a filibuster

${ }^{40}$ See id. at 72-75. This is a long-standing complaint about legal education. See Williams, supra note 19. This disconnect continues even as law schools add "legislation-regulation" courses to the mandatory first-year curriculum, which "follow the familiar, case-oriented approach-relying on appellate opinions and notes and comments on those opinions as the main course materials and the focus of the discussion." John F. Manning \& Matthew Stephenson, Legislation \& Regulation and Reform of the First Year, 65 J. LEG. EDUC. 45, 46 (2015).

${ }^{41}$ Garrett, supra note 17 , at 14.

${ }^{42}$ In the sense of a contractarian theory of the legislative process rather than in the broad sense of the term. NOURSE, MisREADING LAW, supra note 21, at 199 n.3.

${ }^{43}$ Victoria F. Nourse, Elementary Statutory Interpretation: Rethinking Legislative Intent and History, 55 B.C. L. REV. 1613, 1617 (2014) [hereinafter Nourse, Elementary Statutory Interpretation].

${ }^{44}$ See generally NOURSE, MisREADING LAW, supra note 21.

${ }^{45}$ Nourse, Decision Theory, supra note 38, at 92-134.

${ }^{46}$ NOURSE, MiSREADING LAW, supra note 21, at 62.

${ }^{47}$ I generalize Nourse's description of the Congress to all legislatures generally. Any incongruities are noted as necessary.

${ }^{48}$ NOURSE, MisREADING LAW, supra note 21 , at $18-19$.

${ }^{49} \mathrm{Id}$. at 27. The filibuster is available in several state senates. See, e.g., Meghan ReILly, Off. Legis. Rsch., States Limiting Legislative DeBate (2009), https://www.cga.ct.gov/2009/rpt/2009-R-0249.htm (compiling state legislative rules on debate limits). Of the ten largest states, five senates do not impose meaningful limits on debate. See id.; see also 2019 U.S. Population Estimates Continue to Show the Nation's Growth Is Slowing, U.S. CENSUS BUREAU (Dec. 30, 2019), https://perma.cc/Y45T-3MDF (showing top ten states by population). There may be other procedural constraints that create a supermajoritarian difficulty. For example, the Texas Senate's three-fifths "rule" - a practice supported by a combination of certain Senate rules read together with practical circumstances - requires the consent of a supermajority to take up any measure for consideration. See SteVe BickerstafF, Lines In THE SAND: Congressional Redistricting In TeXAS AND THE DownFall of TOM DeLAY 115 (2007). In use since Reconstruction, the three-fifths rule works as a reverse-filibuster: a senator can get a bill to the floor only by demonstrating extraordinary support for it. See 
requires sixty votes, meaning that a minority can (and often does) stall legislation. ${ }^{50}$ This "supermajoritarian difficulty" means that "legislative action requires massive consensus." 51

When legislating - "actively translat[ing] ideas into laws"- these members must speak to multiple audiences: first, the "people and [then] expert lawyers, judges, and administrators." 52 "Statutes... are exercises in communication along two conflicting dimensions - communication between [legislators] and citizens (the vertical dimension) and between legislatures and courts and agencies (the horizontal dimension)." "53 This creates a "multiple audience" problem, as "the demands of a popular electoral audience" may, and likely do, compel the legislature to "ignore precision and the lawyerly voice." ${ }^{, 54}$ Taken together, then, the electoral connection, the multiple audience problem, and the supermajoritarian difficulty create a strong structural preference for legislators relying on intentional ambiguity, redundant provisions, and vernacular language in order for legislation to pass. ${ }^{55}$ The result: "statutory language is often an amalgam of legal and popular meaning."

Nourse skillfully takes on these three theories and shows how each fails to achieve its publicly articulated purpose. All three theories fail to account for legislatures as institutions distinct from courts, with different values operating under different restraints. Textualists are not very forgiving of legislatures, viewing them as undisciplined lawgivers more inclined to political bargaining and less inclined to principled lawgiving. "If we take the textualists' view of Congress-as-chaos to its extreme, then why should we look to text? A truly chaotic Congress could not create plain meaning." ${ }^{57}$ Purposivists are too forgiving of legislatures, viewing them as arenas where "reasonable persons pursu[e] reasonable purposes reasonably." 58 "But

Bill Hobby, How Things ReAlly Work: LeSSONS From a LifE IN Politics 133 (2010); see also John David Rausch, Jr., The Politics of Legislative Procedure, in WiLliam EARL MaXWELl, ERNEST CRAIN \& AdOLFO SANTOS, TEXAS POLITICS TODAY 209 (2011-2012 ed. 1978).

${ }^{50}$ See NOURSE, MisREAding LAW, supra note 21 , at 27. To be clear, Nourse also ascribes part of the supermajoritarian difficulty to the fact that each state is entitled to equal, rather than proportional, representation in the Senate, and thus small states can form a minority to block legislation. Id. at 27-28. Much of the filibustering activity in the late twentieth and early twenty-first centuries has been undertaken by the political minority in the Senate, which does not neatly overlap between large and small states, in an agenda-setting function. See Gregory Koger, Filibustering and Partisanship in the Modern Senate, in PARTY AND PROCEDURE IN THE UNITED STATES CONGRESS 217, 221-26 (Jacob R. Straus ed., 2012). Even if one party represented most of the small states and another represented most of the large states, the same dynamic would still likely be present in the states in which senate districts may be gerrymandered to weigh rural interests over urban interests.

${ }^{51}$ NOURSE, MiSREADING LAW, supra note 21, at 28.

${ }^{52} \mathrm{Id}$. at 20-21 (internal quotation marks omitted).

${ }^{53} \mathrm{Id}$. at 26.

${ }^{54} I d$. at $25-27$.

${ }^{55} I d$.

${ }^{56} I d$. at 26.

${ }^{57} I d$. at 15 . Nourse engages in an extended critique of "petty textualism" and the use of statutory construction canons to show that textualism is "ideologically manipulable," capable of producing counterintuitive results that expand, rather than restrict, the meaning of a text, and highly reflective of the textualist's own individual bias; thus, Nourse shows textualism does not constrain judges from substituting their judgment for the legislature's, but rather the opposite. See id. at 44, 103-54.

${ }^{58}$ Id. at 47 (citing McNollgast, Positive Canons: The Role of Legislative Bargains in Statutory Interpretation, GEO. L.J. 80, 705, 715 (1992)). 
if [the] Congress reasons so well, every statute should be plainly reasonable, not ambiguous enough to send judges running to the statute's history ...."59 Finally, positive political theorists vacillate between textualists and purposivists, with some viewing the Congress as an irrational "devil" and others viewing it as an efficient "angel." $" 60$ Taken to "its logical extreme, then, [under this view,] interpretation would be least of our problems; government would be impossible or unnecessary." 61

Nourse instead describes a distinct, straightforward approach to statutory interpretation by lawyers practicing in and before the political branches. These lawyers read legislation against a background knowledge of the legislative process to answer the fundamental question: what did the legislature decide? ${ }^{62}$ Five principles form this background knowledge:

1. Principle 1: "Statutes Are Elections": There are winners and losers in the legislative process; because of this, "loser's history"- statements and actions by legislators who did not vote for the bill's passage - should not be used by the courts "for the authoritative meaning of a law. The gold standard for legislative evidence is a core bipartisan agreement." 63

2. Principle 2: "Statutes Follow a Sequence": Statutory text is shaped by a sequential legislative process; "later text and legislative evidence may trump earlier legislative evidence" just as, for example, a Supreme Court decision will control over a trial court's decision. ${ }^{64}$

3. Principle 3: "[Legislative] Rules Can Help Interpret Statutes": Legislative procedure is designed to resolve conflicts over the final text between legislative coalitions. These "rules ... can provide interpretative guidance" much like the judicial canons of construction. ${ }^{65}$

4. Principle 4: "Typologies of Legislative History May Mislead": The first three principles - "conflict, sequence, and rules"-mean that there is not a hierarchy of legislative history in which one type, such as committee reports, are to be consistently valued over another type, such as floor statements.

${ }^{59}$ NOURSE, MiSREADING LAW, supra note 21, at 15.

${ }^{60} \mathrm{Id}$. at 15 .

${ }^{61} I d$.

${ }^{62}$ Nourse, Elementary Statutory Interpretation, supra note 43, at 1614-20. For a contrary view that expert knowledge of legislative procedure is superfluous to statutory interpretation, see generally Ryan D. Doerfler, Who Cares How Congress Really Works, 66 DuKE L.J. 979 (2017). Doerfler does not completely engage with Nourse's theory, her proofs, and her careful explanation of legislative evidence in context to reach his conclusion that "appealing to formal norms adopted by [the] Congress fails as a general method for substantiating attributions of legislative intent." See id. at 1010-13. For instance, he considers the question of proper attribution of intent when a bill has been amended before passage and "how to reconcile conflicting, uncoordinated intentions" of committee members and amendment authors. Id. at 1016-17. He argues that legislative procedure does not provide an answer to the question. Id. at 1017. Nourse offers several explanations, including, among other things, whether the amendment appears in an amendment proposed long after the committee text is reported, or whether the amendment was offered by an opponent of the bill. NOURSE, MiSREADING LAW, supra note 21, at 73-76, 83-85.

${ }^{63}$ NOURSE, MisREADING LAW, supra note 21 , at $68-79$.

${ }^{64} I d$. at $69,79-85$.

${ }^{65} \mathrm{Id}$. at $69,85-88$. 
Rather, the best legislative evidence depends on when it occurs, how it occurs, and whether it is reflects a bipartisan consensus. ${ }^{66}$

5. Principle 5: "What Is Unthinkable to a Judge May Be Quite Thinkable to a [Legislator]": Because legislative rules create "process-based expectations" that shape the legislature's decision, courts should recognize that what judicially might be considered an absurd result is instead precisely the result dictated by faithful application of the rules. ${ }^{67}$

Under legislative decision theory, lawyers rely on the "public evidence of [the] context" of the legislature's action read in light of its "rules of proceeding" to determine a statute's meaning. ${ }^{68}$ Constitutionally sanctioned — unlike judicial canons of construction "and every other (traditional) method of statutory interpretation" 69 legislative rules provide "a contextual code" for determining what the legislature did or did not do in light of a majoritarian process "leading to conduct — enacting a law." 70

While "the idea of legislative intent has been a highly durable organizing principle in the law of statutory interpretation," $" 71$ it has been subject to an interminable debate centering on "whether [the] Congress has a mind" ${ }^{, 72}$ and the efficacy of endeavors to "think [one's] way as best [one] can into the minds of the enacting legislators and imagine how they would have wanted the statute applied to the case at bar." ${ }^{73}$ Of necessity, the traditional search for legislative intent is one of reconstructing an intent to support "claims about the specific way the legislature meant to answer the precise question at issue" in difficult cases where it is more likely than not that "the legislature gave no particular thought to the [interpretive issue] and had no intent concerning it." 74

Under legislative decision theory, the traditional search for, or disdain of, legislative intent gives way to a fruitful search for pragmatic intent where "[a]ctionin-context yields the necessary information to determine meaning." 75 The search for pragmatic intent is focused on legislative evidence that reflects majoritarian group decisions made according to the legislature's own procedures and does not require an

${ }^{66} I d$. at $69,88-91$.

${ }^{67} I d$. at $69,91-95$.

${ }^{68} \mathrm{Id}$. at $135-36$.

${ }^{69} \mathrm{Id}$. at $162-67$.

${ }^{70}$ See id. at $142-44,146-47$.

${ }^{71}$ John F. Manning, Without the Pretense of Legislative Intent, 130 HARV. L. REV. 2397, 2405 (2017).

${ }^{72}$ Succinctly, this is the "metaphysical" question of whether the legislature, as a group of individuals, can have a single, occurrent mental state at the time of enactment. See NourSE, MisREADING LAW, supra note 21, at 137-46. Intent skepticism takes the view that the legislature cannot have such a mental state because the internally held, largely unrevealed and practically unascertainable state of mind of each relevant participant in the legislative process is neither contemporaneously in agreement, nor properly delegated to a smaller groupand thus cannot be properly aggregated. See, e.g., Manning, supra note 71, at 2406-07; NOURSE, MISREADING LAW, supra note 21, at 144-46. Again, this is a gross oversimplification, but it suffices for our purposes here.

${ }^{73}$ Richard A. Posner, Statutory Interpretation -In the Classroom and in the Courtroom, 50 U. CHI. L. REV. 800, 817 (1983).

${ }^{74}$ Manning, supra note 71, at 2410 (citing HenRy M. HART, JR. \& AlberT M. SACKS, The Legal Process 4-5 (William N. Eskridge, Jr. \& Philip P. Frickey eds., Foundation Press 1994) (1958)).

${ }^{75}$ NourSe, MisREAding LAW, supra note 21, at 144. 
inquiry into the minds of legislatures. ${ }^{76}$ This is how legislators understand what happened during a statute's enactment, and lawyers should use that evidence to determine a statute's effect. ${ }^{77}$ Legislative decision theory embodies traditional legal reasoning by "infer[ing] intent from action or behavior." "78 "The only real way to make sense of [the legislature's] decisions is [to] start at the end [and] reverse engineer a text that is made sequentially over time" as dictated by legislative procedure. ${ }^{79}$

Nourse illustrates the application of legislative decision theory with several examples. One example, analyzing judicial confusion over the meaning of the word "utilized" in the Federal Advisory Committee Act, which subjected any panel "established or utilized" by the President to certain transparency requirements, ${ }^{80}$ is helpful here. In Public Citizen v. U.S. Department of Justice,${ }^{81}$ which is "taught as a controversial case," ${ }^{82}$ the Supreme Court considered whether the Act applied to the American Bar Association's judicial nomination screening committees.

The majority read the word in a narrow, technical sense to find that the committees were not "utilized" by the President and were not subject to the Act; to hold otherwise would permit a "woolly" word to produce absurd results by applying the transparency requirements to practically every meeting of the President with two or more persons. ${ }^{83}$ The concurring Justices thought the committees were plainly used by the President and that the majority's approach "amend[ed] the statute by judicial interpretation," but also thought the Act unduly interfered with the President's constitutional powers of appointment. ${ }^{84}$ Both sides examined the enactment history in reaching their conclusions. ${ }^{85}$

In Public Citizen, we can see how Nourse's five principles work in practice to aid judges in straightforwardly reading legislation. ${ }^{86}$ As Nourse points out, the Court could have easily resolved Public Citizen by "understanding when [the] Congress added the term 'utilize[d]' to the statute." ${ }^{\text {C7 }}$ The term was added for the first time when the bill was in conference committee and was "contrary to the bills passed in both [houses]"; under both U.S. House and U.S. Senate rules, a conference committee may not alter text that is not in disagreement between the two houses ${ }^{88}$ illustrating Principle 3, "Legislative Rules Can Help Interpret Statutes." No other

\footnotetext{
${ }^{76} \mathrm{Id}$. at $141-43$.

${ }^{77}$ See id. at 153-56 (arguing that evidence of "minority views and post hoc manipulations" should not be used because they conflict with the majoritarian decision-making process that produced the statute). Id. at 123 .

${ }^{78} I d$. at 142 .

${ }^{79} \mathrm{Id}$. at 157 .

${ }^{80}$ Nourse, Decision Theory, supra note 38, at 92-93.

${ }^{81}$ Public Citizen v. U.S. Dep't of Justice, 491 U.S. 440 (1989).

${ }^{82}$ Nourse, Decision Theory, supra note 38, at 93.

${ }^{83}$ Public Citizen, 491 U.S. at 464-65.

${ }^{84}$ Id. at $469-70,482-83$.

${ }^{85} I d$. at $455,458-63,474-76$.

${ }^{86}$ Nourse herself does not use Public Citizen to illustrate all five principles; I do so both for economy reasons and because I think it can bear the weight of the illustration.

${ }^{87}$ Nourse, Decision Theory, supra note 38, at 93.

${ }^{88}$ Id. at $93-94$.
} 
enactment history in Public Citizen matters, because "the conference report was simple, strong, and proximate" and "was the last act on the precise statutory term at issue" 89 - illustrating Principle 2, "Statutes Follow a Sequence." Because a legislator would not read the conference committee report as materially changing the text, a court should not read it that way either. ${ }^{90}$ The conference report's silence on the meaning of the unaltered text is precisely what a legislator would expect, while "[a] judge, however, might read this silence as erroneously significant [rather than] foreordained" by the rules ${ }^{91}$-illustrating Principle 5, "What Is Unthinkable to a Judge May Be Quite Thinkable to a [Legislator]." The majority recited committee reports from prior Congresses considering legislation that did not pass $;{ }^{92}$ those reports of a failed statutory election are contextually divorced from the enacting Congress's process - illustrating Principle 1, "Statutes Are Elections." Moreover, even when the majority cited committee reports from the enacting Congress, it overlooked that the committee reports came before the disputed term entered the final text and the conference report was, in context, the controlling document-illustrating Principle 4, "Typologies of Legislative History May Mislead." Public Citizen, as explained by Nourse, stands for the proposition that one should "never read legislative history without knowing [the] Congress's own rules." 93

Legislative decision theory provides a "minimalist" theory, unencumbered by cognitive biases flowing from lawyers' common-law education, that "provides an important corrective to debates on statutory interpretation." reinforcing rule of statutory interpretation" that, among other things, "reduc[es] incentives for legislative manipulation" and increases incentives for following its own rules. ${ }^{95}$ There are obstacles, however, on the path to implementing this theory.

\section{B. Why We Haven't Been Doing It AlReady: Legal Citation as an OBSTACLE TO WIDER IMPLEMENTATION OF LEGISLATIVE DECISION THEORY}

There are several obstacles that must be overcome before legislative decision theory can be widely implemented by lawyers. One issue Nourse describes is teaching lawyers and "judges how to read the legislative record the way a [legislator] would read the record." 96 Legislatures must "do a lot more to increase the intelligent consumption of" legislative evidence by making it easier to find in online databases and by identifying winners and losers through annotations to votes. ${ }^{97}$ Legislatures

\footnotetext{
${ }^{89} I d$. at 95 .

${ }^{90} \mathrm{Id}$.

${ }^{91}$ NoURSE, MisREADING LAW, supra note 21, at 92-93.

${ }^{92}$ Public Citizen v. U.S. Dep't of Justice, 491 U.S. 440, 455-60 (1989).

${ }^{93}$ Nourse, Decision Theory, supra note 38, at 92, 95-97.

${ }^{94}$ Kevin McGravey, Book Review, 15 PERSPECTIVES ON POLITICS 1134, 1135 (2017) (reviewing NouRSE, MisREADING LAW, supra note 21 and K. SABEEL RAHMAN, DEMOCRACY AGAINST DOMINATION (2016)).

${ }^{95}$ NOURSE, MISREADING LAW, supra note 21, at 100

${ }^{96}$ See id. at 186.

${ }^{97}$ See id. at $186-87$.
} 
should also provide context by having independent staff agencies prepare authoritative process-tracing timelines for all major legislation that provide the key information needed to reverse engineer a text. ${ }^{98}$ Each house "should . . create new rules, or enforce existing ones, to avoid abuse" of process, such as post-enactment manufacturing of reports and floor colloquies. ${ }^{99}$ Legislatures should accord courts the respect they desire by relieving judges from crushing dockets filled with "politically [un]controversial" matters through "bipartisan default rules" addressing "attorneys' fees[,] expert witnesses, statutes of limitation, extraterritorial effect, and similar matters ... to limit litigation." 100 Finally, the judicial confirmation process should be "regularized" into a transparent, bipartisan process in which "senators must insist ... that nominees pledge not to blind themselves to legislative evidence."101

Another obstacle to the wider implementation of legislative decision theory, and one that appears to have been overlooked, is current legal citation practice. Quite simply, legal citation under the Bluebook (and other jurisdiction-specific or specialized practice citation manuals) does not permit lawyers to describe the "public evidence of [the] context" of the legislature's action read in light of its "rules of proceeding"102 - Public Citizen demonstrates this. Despite the importance of the conference report in legislative procedure, the Bluebook forms do not differentiate between committee and conference reports on a bill, and the important differences are unexplained or unindicated. ${ }^{103}$ This reflects lawyers' unfamiliarity with "congressional basics," which has caused Supreme Court "[J]ustices [to] debate [whether] a conference report [is] really different from a committee report." 104 The Bluebook's lack of care in this area stands in stark contrast to the care with which the Bluebook requires distinguishing the weight of authority of cases, their prior or subsequent history, and their precedential value. ${ }^{105}$

There are other ways in which legal citation prevents the expert process tracing and reverse engineering of a statute. Procedural restraints govern the legislative process, and there are consequences for violating or disregarding those rules. Further, there are multiple versions of the text and amendments thereto, and these form the basis for each stage of formal deliberation. These restraints and versions are not explained by, and the Bluebook does not require the use of, explanatory parentheticals to note procedural postures or to differentiate text versions. ${ }^{106}$ Knowing whether an amendment died because it was voted down or because it violated chamber rules is useful in understanding whether the chamber

\footnotetext{
${ }^{98}$ See id. at 187.

${ }^{99} \mathrm{Id}$.

${ }^{100}$ See id. at $187-88$.

${ }^{101}$ See id. at 188 . This proposal will have less relevance in states where judges either are popularly elected or regularly rely on legislative evidence.

${ }^{102}$ See id. at $135-36$.

${ }^{103}$ See BLUEBOOK 20th ed., supra note 1 , at 135, 138. This difference has not been easily grasped by judges.

${ }^{104}$ NOURSE, MisREADING LAW, supra note 21, at 3. Which, of course, it is. Id.

${ }^{105}$ BLUEBOOK 20th ed., supra note 1, at 106-13.

${ }^{106} I d$. at 136 ("A parenthetical indicating the date and stage of the bill may be provided in order to distinguish among multiple versions." (emphasis added)).
} 
made a substantive decision to reject the amendment's language. ${ }^{107}$ Legal citation does not provide any method for indicating a chamber's action on an amendmentindeed, it does not provide a method for citing amendments at all. ${ }^{108}$

\section{Legal Citation as Legal Thought}

"Without citation, there is simply no traditional legal [thought]." 109 Legal thought - the process of constructing a legal argument for or against a propositionrequires a keen appreciation for, and attentive use of, the relevant authorities. "It is not without interest and importance that lawyers and judges refer to the things they cite as authorities and that a brief is sometimes called a "memorandum of points and authorities." "110 More than any other discipline, "law is . . an authoritative practice" that relies on careful accounting of the reliability of authority. ${ }^{111}$

Thus, "the pieces of information someone might need in order to [construct a citation and] evaluate the legal support offered for a given proposition ... cover[] every single point in the standard case citation format[:]

1. What is the name of the case;

2. How to find it: where in the reporters it is assembled and archived;

3. When it was decided and its contemporary relevance;

4. Which court decided it, the level of its authoritativeness, and its jurisdiction;

5. Whether it is good law. Have any subsequent cases rethought, rewritten, or substantially changed its holdings?

6. The precise meaning of the decision;

7. Where in the text of the decision that central meaning can be found, by page number; and

8. Why this case is being introduced in this time and place: that is, how it related to the assertion for which it is being raised."112

"[B]y treating [legal citation] not as random blobs of information" mechanically strung together, "but instead containing everything you need" to speak about a case, "the conventions of basic citation form become a fairly simple, almost elegant way of presenting this information in readily-available, comprehensible form." ${ }^{\prime 13}$ Legal citation influences legal thought and shapes the direction of the law

\footnotetext{
${ }^{107}$ For example, "[t]he deletion of a provision in a pending bill discloses the legislative intent to reject the proposal." Smith v. Baldwin, 611 S.W.2d 611, 616-17 (Tex. 1980).

${ }^{108}$ See BLUEBOOK 20th ed., supra note 1, at 136-42.

${ }^{109}$ David S. Coale, Classical Citation, 3 J. APP. PrAC. \& Process 733, 734 (2001).

${ }^{110}$ Schauer, supra note 25 , at 1934.

${ }^{111}$ See id. Schauer thinks that this reliance on authoritative sources elevates that reliability over "the content (or even the correctness) of ideas, arguments, and conclusions," but that claim seems to be as much of an exaggeration as the one he is criticizing. See id. at 1934 n.11 (stating that Posner "exaggerates" when he wrote that "authority and hierarchy play a role in law that would be inimical to scientific inquiry").

${ }^{112}$ Franklin, supra note 22, at 131 .

${ }^{113} I d$. at 132 .
} 
by leading the judge to inescapable, sometimes counterintuitive, rulings in favor of a litigant. ${ }^{114}$ It does this in at least three ways. ${ }^{115}$

First, citation provides logical support for arguments by explaining how each authority supports a legal conclusion urged to a court (e.g., the precedential status of each authority). ${ }^{116}$ Failure to appropriately document a proposition of law with proper citation, then, dooms that proposition. ${ }^{117}$ Thus, a lawyer must explain how each item of legislative evidence relates to her argument.

Second, citation establishes the lawyer's personal credibility and that her arguments are legally and ethically sound. For example, consider the use of authority that contradicts the authority one uses to support a proposition. Contrary to one critique that signaling adverse authority is "substantively irrelevant to convincing a reader of the point," 118 what the practice demonstrates is that the lawyer is fully aware of both the ethical duty of candor to the tribunal ${ }^{119}$ and her facility with the doctrine residing in the texts. ${ }^{120}$ A lawyer who believes she may safely ignore contrary authority raises several questions about her competence or truthfulness. ${ }^{121}$

Finally, citation increases an argument's persuasiveness when it demonstrates the underlying policy of a legal rule, rather than dryly reciting precedents, ${ }^{122}$ such as when public rights trump private morals. ${ }^{123}$

One can easily see that these three purposes apply with equal force to legislative evidence under legislative decision theory. First, required disclosure of the precedential status of legislative evidence and its support for a stated proposition

\footnotetext{
${ }^{114}$ SCHAUER, THINKING LIKE A LAWYER, supra note 23, at 37-41, 65-66.

${ }^{115}$ See Coale, supra note 109, at 733-35.

${ }^{116} \mathrm{Id}$. at 734; BLUEBOOK 20th ed., supra note 1, at 58-60 (explaining the placement of citations and signals used to indicate an authority's support for a proposition).

${ }^{117}$ See, e.g., Religious of Sacred Heart v. Houston, 836 S.W.2d 606, 611 (Tex. 1992) (affirming appellate court's refusal to rely on a prior opinion decided "without citation to authority" in which the offending court surveyed a number of cases to reach its conclusion but did not include pinpoint citations for any, save one).

${ }^{118}$ Michael Bacchus, Strung Out: Legal Citation, The Bluebook, and the Anxiety of Authority, 151 U. PA. L. REV. 245, 267 (2002).

${ }^{119}$ See TeX. Disciplinary R. Prof'L CONDUCt R. 3.03(a)(4), reprinted in TeX. Gov'T Code ANN., tit. 2, subtit. G, app. A (West 2013); accord MOdel RUles OF PROF'L CONDUCT r. 3.3(a)(2) (AM. BAR Ass'N 2016). Although the rule does not require "a disinterested exposition of the law [by the lawyer, the lawyer] should recognize the existence of pertinent legal authorities.... The underlying concept is that legal argument is a discussion seeking to determine the legal premises properly applicable to the case." TEX. DISCIPLINARY RULES PROF'L CONDUCT R. 3.03 cmt. 3 (1989).

${ }^{120}$ Douglas R. Richmond, The Ethics of Zealous Advocacy: Civility, Candor, and Parlor Tricks, 34 TeX. TECH L. REV. 3, 41 (2002) ("Good advocates freely reveal adverse authority, accompanied by arguments criticizing the cases or other authority disclosed or distinguishing them.").

${ }^{121}$ See, e.g., HL Farm Corp. v. Self, 820 S.W.2d 372, 375 n.2 (Tex. App.-Dallas 1991, writ granted) (condemning appellant's "attorney [for] knowingly ignoring contrary authority [cited in appellee's brief] that [was] directly on point" after attorney confessed at oral argument he knew of the contrary authority, but did not cite it because he thought it was "wrong").

${ }^{122}$ Coale, supra note 109 , at 735 .

${ }^{123}$ See, e.g., Milliken v. City Council of Weatherford, 54 Tex. 388, 389, 393 (1881) (striking down city ordinance barring prostitutes' residence within the city's limits under constitutional provision prohibiting common-law outlawry, which withdrew "the protection of the law" from outlaws, on the grounds that the prostitutes, while not meeting contemporaneous standards of womanhood, were "still human beings, entitled to shelter and the protection of the law"); see also David J. Seipp, The Distinction Between Crime and Tort in the Early Common Law, 76 B.U. L. REV. 59, 64 (1996) (explaining the operation of outlawry).
} 
would mean, for example, that the superior status of the conference committee report in Public Citizen would have been explicit and any detours into the House report unfruitful. Second, the requirement to disclose contrary authority would prevent picking and choosing legislative evidence and require that lawyers would have to disclose the legislative evidence that is more proximate to the relevant decision. Lawyers could not, for instance, spend time discussing a House report and House debate that happened long before contested language was added by the Senate after cloture without also spending as much time on the Senate's work. ${ }^{124}$ Finally, the enhanced persuasiveness of an argument's additional grounding in the underlying policy would mean that lawyers would rely on the legislative evidence furnished by uncontradicted floor debate to understand, for example, that a deadline for an interlocutory appeal of a remand order in a class action suit was a ceiling, not a floor, because the policy behind the bill was reducing delay in adjudicating these costly suits. $^{125}$ Because legal citation is mostly unconcerned with legislation by design, lawyers deprive themselves of their tested methods for providing comprehensibility in legal argument.

\section{Legal Citation Is Designed for Common-Law Thought}

We now know that the Bluebook was conceived as an effort by Karl Llewellyn and William Field, when they were Yale Law Journal editors, to design and enforce uniformity of citation in American law reviews, extend this uniformity to the American Law Institute restatements, and eventually direct the citing of all case law. ${ }^{126}$ Llewellyn and Field sought "uniformity" in citation not for bibliographic purposes but to permit the sophisticated use of case law when reasoning from authority. "[Focused] almost entirely on the citation of cases," the guide reflects that,

[a]bove all, Llewellyn was committed to "case law."... In all [his] writings, Llewellyn tried to demonstrate the meaning and uses of a casewhat a specific case meant and didn't mean as a precedent, and how best to understand the evolution of case law through the common law system and tradition. . . . Since Llewellyn's terrain was the attentive and meticulous deployment of case law, not the disregard of case law, it is very understandable ... that Llewellyn would greatly want a reliable system of legal citation - most importantly a reliable system of citing case law. ${ }^{127}$

\footnotetext{
${ }^{124}$ As Nourse demonstrates was the case in United Steelworkers of American v. Weber, 443 U.S. 193 (1979). See NOURSE, MiSREADING LAW, supra note 21, at 82-83.

${ }^{125} \mathrm{Id}$. at $90-91$.

${ }^{126}$ See Fred R. Shapiro \& Julie Graves Krishnaswami, The Secret History of the Bluebook, 100 MINN. L. REV. 1563, 1575, 1579 (2016). The two editors' 1920 eight-page booklet The Writing of a Case Note contained a page of citation rules. Id. at 1569-75. Those rules were "the embryo that has grown into the 582-page behemoth that is the Bluebook's 20th edition in 2015." Id. at 1573-74.

${ }^{127}$ Id. at 1575 (citing E-mail from Paul Gewirtz, Professor, Yale L. Sch., to Fred. R. Shapiro, Assoc. Librarian for Collections \& Access and Lecturer in Legal Research, Yale L. Sch. (Aug. 11, 2015, 14:57 EST) (on file with Shapiro \& Krishnaswami)).
} 
Against this background, the Bluebook was not created to serve "Langdellian orthodoxy [focused] on a few thousand judicial decisions," 128 fixed in time and served as the whole repository of legal doctrine. ${ }^{129}$ Instead, the Bluebook was born to serve the "grand and persuasive common law tradition"130 in which "great Judges . . . kept the law a living institution, moving with our civilization and doing justice as men can see it." 131 And as the Bluebook was created just before statute-making began in earnest under the New Deal, ${ }^{132}$ legislation had not assumed its modern importance and thus required little attention from Llewellyn and Field and their successors.

As a general work, the Bluebook cannot cover most specialized questions. ${ }^{133}$ Reliance on its national system "necessarily bear[s] limited relation to the local experience and, [left unchecked, could] possibly do away with it altogether." ${ }^{134}$ This is best demonstrated by the special cases of Texas and New York in according precedential status to state court decisions.

Due to its historically high workload in supervising fourteen intermediate appellate courts, the Texas Supreme Court developed a robust, rather sophisticated, and sometimes confusing "writ history" system of assigning notations to petitions for review that accorded varying levels of precedential effect to the underlying Courts of Appeals opinions. ${ }^{135}$ For example, the notation "writ refused"136 means that both "the

\footnotetext{
${ }^{128}$ Alfred E. Conard, A Lovable Law Review, 44 J. LEG. EDUC. 1, 4 (1994).

${ }^{129}$ See LAWRENCE M. Friedman, A History OF AMERICAN LAW 473 (3d ed. 2005).

${ }^{130} \mathrm{~S}$. Alan Childress, Foreword to Karl N. Llewellyn, The Common LaW Tradition: DeCiding APPEALS ii (2015 ed. 1960). Llewellyn's commitment to case law was well-known by his contemporaries. See, e.g., Arthur L. Corbin, A Tribute to Karl Llewellyn, 71 YALE L.J. 805, 807-08 (1962). This is not unsurprising to anyone deeply familiar with Llewellyn's work; "[a]lthough Llewellyn gleefully exposed the manipulability of precedent and the openness of the rules of statutory interpretation, he consistently disclaimed the most radical implications of these observations ....” Brian Z. Tamanaha, Understanding Legal Realism, 87 TEX. L. REV. 731,766 (2009). Because a number of factors, including legal rules and doctrine, "prompt judges to engage in a good-faith effort to conduct an unbiased search for the correct legal result," Llewellyn thought that "[a] skilled lawyer asked to predict the fate of a case on appeal ... ought "to average correct prediction of outcome eight times out of ten, and better than that if he knows the appeal counsel on both sides or sees the briefs." Id. at 76667 (emphasis added) (quoting KARL N. LLEWELLyn, THE COMMON LAW TRADITION: DECIDING APPEALS 1926, 45-51 (1960)).

${ }^{131}$ Corbin, supra note 130 , at $807-08$

${ }^{132}$ See CALABRESI, supra note 17 , at $44-45$.

${ }^{133}$ There are citation manuals for specific states, for specialized practices, or as supplements to the Bluebook. Courts have adopted these manuals, issued their own preferred citation forms, or follow a unique house style passed down from reporter to reporter. And while lawyers may, and do, use the style manuals issued by their state's official reporters, state bar associations have also issued state-specific manuals. Specialty bars have followed suit for their practice areas, as have federal and state administrative agencies.

${ }^{134}$ Pierre Legrand, Sigla Law, 23 INT'L J. LEGAL INFO. 123, 136 (1995). The same also occurs with foreign competitors. For example, the Bluebook's handling of Canadian materials does not express the folkways of lawyers there and is displaced by a more faithful expression. Barbara Bintliff, Guide to Legal Citations: A Canadian Perspective in Common Law Provinces, 5 Legal Reference SeRVS. Q. 114, 115-17 (1985) (reviewing Chin-Shih Tang, Guide to Legal Citation: A Canadian Perspective in Common Law PROVINCES (1984)) (comparing the Bluebook's treatment of Canadian materials with the Guide and concluding that the Guide "does reflect the actual title and current Canadian usage more accurately").

${ }^{135}$ See Hon. Ted Z. Robertson \& James W. Paulsen, Rethinking the Texas Writ of Error System, 17 TEX. TECH L. REV. 1, 4-42 (1986); see also James Hambleton, Notations for Subsequent Histories in Civil Cases, 65 TEX. B.J. 694, 694-96 (2002).

${ }^{136}$ Under the current discretionary review system, petitions for review have replaced applications for writs of error, and the word "writ" in the notation is replaced by "pet." Because our concern here is historical, I use
} 
judgment of the court of appeals is correct and ... the principles of law declared in [its] opinion ... are correctly determined ...."137 A "writ refused" opinion has the same precedential effect as a Supreme Court opinion; all lower courts must apply that court of appeals opinion exactly as they would the court's own opinions even if it requires "reluctantly follow[ing] a poorly reasoned ... precedent." 138 Correctly cited writ history "immediately assists [a] court in evaluating the authority." 139

The writ history system created "some peculiarities in Texas citations," 140 for which Texas lawyers demanded guidance to avoid vague understandings of, and loose reckoning with, a case's writ history. ${ }^{141}$ In 1966, the Texas Law Review published the first edition of the Texas Rules of Form ${ }^{142}$ - the Greenbook-which made "very great contributions ... to an understanding of the peculiarities of Texas law" through careful explanation of "the precedential effect[s] of various Supreme Court actions" by describing the appellate system's historical workings and the implications of those workings on discerning precedent. ${ }^{143}$ Viewed by Texas lawyers and judges as a comprehensive system governing the citation of most materials that would be cited to Texas tribunals, ${ }^{144}$ the Greenbook has effectively displaced the Bluebook in matters of Texas law. ${ }^{145}$

the older notations.

${ }^{137}$ TEX. R. APP. P. 133(a) (repealed). This is not the case for petition denied cases in the Court of Criminal Appeals. See Andrew T. Solomon, A Simple Prescription for Texas's Ailing Court System: Stronger Stare Decisis, 37 St. MARY's L. J. 417, 434 n.58 (2006).

${ }^{138}$ See '21' Int'l Holdings, Inc. v. Westinghouse Elec. Corp., 856 S.W.2d 479, 485 (Tex. App.-San Antonio 1993, no writ) (Peeples, J., concurring) (applying H. Rouw Co. v. Ry. Express Agency, 154 S.W.2d 143 (Tex. App.-El Paso 1941, writ ref'd)).

${ }^{139}$ Joe Greenhill, Uniform Citations for Briefs: With Observations on the Meanings of Stamps or Markings Used in Denying Writs of Error, 27 TEX. B.J. 323, 323 (1964) [hereinafter Greenhill, Uniform Citations for Briefs]. While the 1964 article includes much of his 1949 material, Greenhill updated his forms in light of both the tenth edition of the Bluebook and Price's Practical Manual. See generally id.

${ }^{140}$ Joe R. Greenhill, Preface of TeXas RULES of Form 3 (Tex. Law Review Ass'n ed., 1st ed. 1966).

${ }^{141}$ See, e.g., Robert W. Stayton, Courts-Jurisdiction of Texas Supreme Court-Act of 1927, 7 TEX. L. REV. 115, 117-25 (1928); E.O. Mather, Comment, Appeal and Error-Application for Writ of Error-Orders of Supreme Court, 9 TEX. L. REv. 562, 562-63, 566 (1928); Fred M. Cassidy, Comment, Appeal and ErrorRefusal of Writ of Error as Approval of Opinion, 15 TEX. L. REV. 124, 124-25 (1936); E.W. Fountain, Current Decisions and Legislation Affecting the Oil Industry, 18 TEX. L. REV. 48, 57-58 (1939); Order Amending Rule Governing the Supreme Court, 131 Tex. v, v-vi (1939); Gordon Simpson, Notations on Applications for Writs of Error, 12 TEX. B.J. 547 (1949); Frank M. Wilson, Hints on Precedential Evaluation, 24 TEX. B.J. 1037 (1961); Zollie Steakley, What the Heck in Two Respects, 30 TEX. B.J. 697 (1967).

${ }^{142}$ GREENBOOK 1st ed., supra note 1 . The book has a very light green cover.

${ }^{143} \mathrm{Id}$. at 45 .

${ }^{144}$ See James W. Paulsen \& James Hambleton, One Book, Two Book, Green Book, Blue Book: Random Observations on the Texas Rules of Form (6th ed.) and that Harvard Book, 52 TEX. B.J. 44, 45 (1989). The first edition of the Greenbook was heralded as "a comprehensive compilation of citation forms for Texas authorities" that "w[ould] soon be adopted by the courts and the Bar as the uniform citation system of the state." New Publication, 29 TEX. B.J. 928 (1966). The Greenbook disclaims being "a complete citation guide" for Texas law and claims it is meant only to "supplement ... [t]he Bluebook to address citation problems unique to Texas.” TeXAs Rules OF Form: THE GREENBOOK v (Texas Law Review eds., 13th ed. 2015). On the other hand, the Greenbook does claim that it "is a lens through which the full spectrum of Texas legal materials may be cited and understood" and "provides the tools to cite Texas authorities with precision." Id.

${ }^{145}$ See Bryan A. Garner, Ten Tips for Writing at Your Law Firm, 85 MicH. B.J. 60, 61 (2006) ("In Texas, every knowledgeable practitioner follows the [Greenbook]."). 
New York has a complex court system as well, ${ }^{146}$ and the New York state courts' Tanbook ${ }^{147}$ provides a highly detailed roadmap for citing New York authorities. "[T] he Tanbook gets New York law right every time, and the Bluebook gets it wrong every time." 148 This includes providing methods ${ }^{149}$ for lawyers to "explain whether a case is binding or persuasive, and if persuasive, how persuasive" in the context of the byzantine state court system. ${ }^{150}$

These two brief examples show that lawyers have refused to be hindered in their thinking about case law when the Bluebook failed to meet the specific circumstances in their jurisdictions. Lawyers, however, have not been as engaged when it comes to the Bluebook's treatment of legislation, with very real consequences.

\section{How Legal Citation Has Hindered Thinking About Legislation}

The Bluebook has shaped our thinking about legislation, and not for the better. Owing to the Bluebook's common-law origins, legislation is treated with less care despite its formal place above cases in the Bluebook hierarchy of authority. ${ }^{151}$ Because of this lack of care, for example, "we no longer read the statutes" enacted by the Congress; "[w]e read imitation law." 152 And unlike the sixteenth edition's changes to signaling practices, ${ }^{153}$ this change occurred practically without notice.

The "real law" is the session laws passed each year by both houses; approved, or acquiesced in, by the President; and compiled in the United States Statutes at Large. ${ }^{154}$ Session laws employ a unique amendatory scheme and are troublesome to read because they require one to locate the older session law being amended and read the old law and the new law side by side to determine what the current law is. ${ }^{155}$ The United States Code "is something like a Cliffs Notes guide to the real law" because it is merely a compilation of the session laws, arranged and rewritten to present a "single clean text," incorporating all session law amendments. ${ }^{156}$

${ }^{146}$ Quintin Johnstone, New York State Courts: Their Structure, Administration and Reform Possibilities, 43 N.Y. L. SCH. L. REV. 915, 915-21 (1999).

${ }^{147}$ Formally, NEW YORK LAW REPORTS STYLE MANUAL (The Law Reporting Bureau of the State of N.Y. ed., 2007) [hereinafter TANBOOK].

${ }^{148}$ Gerald Lebovits, New Edition of State's "Tanbook" Implements Extensive Revisions in Quest for Greater Clarity, 74 N.Y. ST. B. Ass’N J. 8, 14 (2002).

${ }^{149}$ See TANBOOK, supra note 147 , at $\mathrm{v}$.

${ }^{150}$ Lebovits, supra note 148, at 17.

${ }^{151}$ BLUEBOOK 20th ed., supra note 1, at 61.

${ }^{152}$ Tobias A. Dorsey, Some Reflections on Not Reading the Statutes, 10 GREEN BAG 2D 283 (2007).

${ }^{153}$ The sixteenth edition's revisions were the latest in a series of alterations to the Bluebook's instructions for signals, and they were the most significant. Faithfully implementing the sixteenth edition would have resulted in "see" preceding practically every authority directly supporting the cited proposition; that is, "see" would now precede practically every citation to authority —other than a direct quote-for which no other signal was used. Melissa H. Weresh, The ALWD Citation Manual: A Truly Uniform System of Citation, 6 LEGAL WRITING: J. LEGAL WRITING INST. 257, 260 (2000). The seventeenth edition overturned this innovation and returned to the fifteenth edition's rule governing "see." THE BLUEBOOK: A UNIFORM SYSTEM OF CiTATION (Columbia Law Review Ass'n et al. eds., 17th ed. 2000).

${ }^{154}$ Dorsey, supra note 152 , at $283-84$.

${ }^{155} \mathrm{Id}$. at $284,289-91$.

${ }^{156} I d$. at $284-85$. 
The Code "is only 'prima facie' evidence of the law, while the Statutes at Large [are] 'legal' evidence" of the law; when the two conflict, the Statutes at Large prevail. ${ }^{157}$ Lawyers formerly read the Statutes at Large for this very reason, and the Bluebook reflected this; the seventh edition (1947) required a citation to the Statutes at Large first, and then to the Code. ${ }^{158}$ The eighth edition (1949) dropped the requirement for a Statutes at Large citation when a particular title of the Code had been enacted into positive law; the ninth edition (1955) dropped the requirement for a Statutes at Large citation for amendatory laws; and the eleventh edition (1967) practically eliminated the requirement for a Statutes at Large citation, retaining it only when "the language discussed differs materially from that in [the Code]." 159

The Bluebook now equates the Code with "real law," ignoring the Statutes and thus effecting a radical change in how lawyers and judges think about statutes and how to interpret them - a change that, unlike the furor over the Bluebook's change to the signal "see," occurred "without any real debate." 160 A Supreme Court majority may now sensibly claim under the Bluebook that it is examining the "text as written" when it relies on the Code's prior and current compilation of session laws over a minority's dissent based on the actual laws in the Statutes at Large. ${ }^{161}$

\section{IMPROVING CITATION OF LEGISLATION}

In this Part, I apply legislative decision theory to our cases from the Introduction to show that the group-authorized ${ }^{162}$ legislative evidence indicates that the Supreme Court of Texas reached conclusions directly contrary to the Texas Legislature's decisions when it enacted the 1995 revision of the Family Code and the 1981 revision of the Tax Code because the court misread the relevant legislative evidence. Keeping Texas as my case study, I then examine how legal citation mistreats four types of legislative evidence and suggest improvements in this treatment.

\section{A. Applying Legislative Decision Theory to Jones And Fleming FoodS}

The court's misunderstanding of the statutes in Jones and Fleming Foods is attributable to its failure to understand the role of rule-required bill printings. To prevent mistake or misrepresentation, bills are required to be printed at distinct stages in the legislative process so that members have the correct text recommended for

\footnotetext{
${ }^{157} I d$. at $286-87$ (footnote omitted).

${ }^{158} I d$. at 287.

${ }^{159} \mathrm{Id}$. at $287-88$.

${ }^{160} \mathrm{Id}$. at 289.

${ }^{161}$ Id. at 288-89 (discussing Estate of Cowart v. Nicklos Drilling Co., 505 U.S. 469 (1992)).

${ }^{162}$ By "group-authorized," I mean nothing more than the evidence produced by the Legislature during the majoritarian process, i.e., by the "group . . . acting according to [its] procedures." NOURSE, MISREADING LAW, supra note 21 , at $149,153-55$. It does not include "evidence that violates the rules [governing the] group decision." Id. at 153.
} 
consideration. ${ }^{163}$ The printed text is especially critical for the bill's second reading consideration, when amendments may be freely offered and need a simple majority for adoption; those amendments are required to be drawn to the reported text both so that the amendment is on the same subject ${ }^{164}$ and so that it clearly indicates what it is changing in the reported text. ${ }^{165}$

Introduced bills are not printed. ${ }^{166}$ After the introduced bill is referred to committee, neither house may proceed on a bill unless it has been printed and distributed to each legislator. ${ }^{167}$ The first time a bill is printed is when it is favorably reported from committee; this printing shows the committee's amendments, if any, proposed to the introduced text. ${ }^{168} \mathrm{Next}$, it is printed after it is passed by its chamber of origin and sent to the other chamber, showing the complete (or "engrossed") text of the bill as finally adopted by the originating chamber. ${ }^{169}$ If the receiving chamber amends the bill, those amendments are printed with the engrossed text. ${ }^{170}$ If the originating house refuses to adopt those amendments, the bill is sent to a conference committee; the bill is then printed when a conference committee recommends a single text resolving the disagreements between the two houses for their final consideration. ${ }^{171}$

In Texas, only non-controversial bills, such as bills only affecting a specific locality, are routinely not printed at successive stages even after amendment. ${ }^{172}$ If the

${ }^{163}$ E.g., Robert LuCE, Legislative Procedure 518 (1922)

164 TEX. H. Rule 11, § 2, TEX. H.R. 4, 86th Leg., R.S., 2019 H.J. OF TEX. 50, 134; TEX. S. Rule 7.15, TeX. S.R. 5, 2019 S.J. OF TEX. 19, reprinted in Rules of the Senate, TEXAS LEGISLATIVE MANUAL 61.

${ }_{165}$ TeX. H. Rule 11, § 6(j), TeX. H.R. 4, 86th Leg., R.S., 2019 H.J. OF TEX. 50, 136; S.J. OF TEX., 50th Leg., 1st C.S. 95 (1950) (ruling on point of order).

${ }^{166}$ See, e.g., TEX. H. Rule 12, §1(1)(A), TeX. H.R. 4, 86th Leg., R.S., 2019 H.J. OF TEX. 50, 138 (specifying first printing after committee report); TEX. S. RULE 7.12(b), TEX. S.R. 5, 2019 S.J. OF TEX. 19, 19, reprinted in Rules of the Senate, TEXAS LEGISLATIVE MANUAL 59 (specifying first printing after committee report).

${ }^{167}$ Thus, if a committee recommends a bill adversely, it is not printed unless a successful minority report is made. See TeX. S. Rule 11.17, TeX. S.R. 5, 2019 S.J. OF TEX. 19, 19, reprinted in Rules of the Senate, TEXAS Legislative Manual 85; Tex. H. Rule 4, §§ 28-29, TeX. H.R. 4, 86th Leg., R.S., 2019 H.J. OF TeX. 50, 87; TEXAS HOUSE PRACTICE 250 (Hugh L. Brady ed., $3 \mathrm{~d}$ ed. 2017) ("The only purpose of a minority report is to give proponents of a bill one last chance to get a bill printed and before the House for consideration ....").

${ }^{168}$ See, e.g., TeX. H. Rule 12, § 1(a)(1)(A), TEX. H.R. 4, 86th Leg., R.S., 2019 H.J. OF TEX. 50, 138; TEX. S. Rule 7.12(a), TEX. S.R. 5, 2019 S.J. OF TEX. 19, 19, reprinted in Rules of the Senate, TEXAS LEGISLATIVE MANUAL 59.

${ }^{169}$ E.g., TeX. H. RUle 2, § 1(a)(9), TeX. H.R. 4, 86th Leg., R.S., 2019 H.J. OF TEX. 50, 55.

170 See, e.g., TEX. H. RULE 12, § 1(a)(2), TEX. H.R. 4, 86th Leg., R.S., 2019 H.J. OF TEX. 50, 138; TEX. S. RULE 7.21, TEX. S.R. 5, 2019 S.J. OF TEX. 19, 19, reprinted in Rules of the Senate, TEXAS LEGISLATIVE MANUAL 68.

${ }^{171}$ See, e.g., TeX. H. RulE 12, § 1(a)(3), TEX. H.R. 4, 86th Leg., R.S., 2019 H.J. OF TeX. 50, 138; TeX. S. Rule 12.09, TEX. S.R. 5, 2019 S.J. OF TEX. 19, 19, reprinted in Rules of the Senate, TEXAS LEGiSLATIVE MANUAL 96.

${ }^{172}$ See, e.g., SHARON CARTER \& HUGH L. Brady, TeXAs HouSE Rules MANUAL 156 (2019) (stating that "[c]ommittees have no authority to order not printed bills which they report favorably, except local bills, even though such bills may be considered uncontested" and directing clerks to disregard the committee's order and instead print the bill); TEX. S. RULE 11.06, TEX. S.R. 5, 2019 S.J. OF TEX. 19, 19, reprinted in Rules of the Senate, TeXas Legislative MANUAL 80 (providing "a recommendation in a report that a bill which is a local bill be not printed shall be effective as an order of the Senate that the bill be not printed"); TEX. S. RULE 7.12, TEX. S.R. 5, 2019 S.J. OF TEX. 19, reprinted in Rules of the Senate, TEXAS LEGISLATIVE MANUAL 59 (providing that Senators receive notice of bills ordered not printed). 
House decides that a bill is non-controversial and unlikely to attract substantive amendment, it may order the bill not printed by a supermajority vote. ${ }^{173}$ Thus, if a bill is not printed, the members do not have the text of the bill in front of them when they are voting on the bill.

The 1981 codification of the Tax Code in Fleming Foods was ordered not printed by a supermajority of the House and the Senate. ${ }^{174}$ Because it was not printed, members did not have the text of the bill in front of them when they voted, indicating that they decided that the bill's changes to the law were in fact non-substantive and there was no need to read text that was not changing the law. Conversely, the 1995 recodification of the Family Code in Jones was printed because no motion to order the bill not printed was made. ${ }^{175}$ This indicates that the members decided that the bill's changes to the law were presumptively substantive and there might be a need to read its text.

Legislative decision theory, then, indicates that the court incorrectly decided both Jones and Fleming Foods because the group-authorized evidence shows that the Legislature decided it did make a substantive change to the Family Code in 1995 and did not make a substantive change to the Tax Code in 1981. However, legal citation did not permit the court to "read legislative history with[] [a] know[ledge] of [the Legislature's] own rules." "Th6 That is, neither the Bluebook nor the Greenbook acknowledges or provides a method of citing this crucial legislative action-or, for that matter, any others. This is akin to omitting guidance that the weight of a case's authority must be explained in a parenthetical to permit immediate evaluation of its precedential status ${ }^{177}$ or omitting a case's writ history. ${ }^{178}$ The supreme court ignored the contextual code provided by the Legislature's rules and "unwittingly invent[ed] a plain meaning to a statute directly opposed to [the Legislature's] decision."179

Even if one rejects legislative decision theory, a reliable system for citing legislation is essential to demonstrate the meaning of an amended statutory text. ${ }^{180}$ For textualists, then, specialized legal citation for legislation is necessary to avoid fundamental errors about what constitutes the actual text, such as the one made in Lamie v. United States Trustee. ${ }^{181}$ As discussed earlier, the United States Code ("Code") is an unofficial editorial consolidation into a "single clean text" of all current

${ }^{173}$ CARTER \& BRADY, supra note 172 (noting that bills may be ordered not printed only by suspending the rules, which requires two-thirds of the members present).

${ }^{174}$ History of House Bills in the House, H.J. OF TEX., 67th Leg., 4930 (1981) (showing the codification bill ordered not printed); History of House Bills in the Senate, S.J. OF TEX., 67th Leg., 2775 (1981) (same).

${ }^{175}$ History of House Bills in the House, H.J. OF TEX., 74th Leg., A68 (1995) (reflecting lack of a successful motion to order the bill not printed); History of House Bills in the Senate, S.J. OF TEX., 74th Leg., 4682 (1995) (same).

${ }^{176}$ See Nourse, Decision Theory, supra note 38, at 92, 95-97.

${ }^{177}$ BLUEBOOK 20th ed., supra note 1, at 107-10.

${ }^{178}$ GREENBOOK 14th ed., supra note 1 , at 21.

${ }^{179}$ NOURSE, MisREADING LAW, supra note 21, at 64, 100-01, 135-36.

${ }^{180}$ Cf. Shapiro \& Krishnaswami, supra note 126, at 1575 (citing Gerwitz e-mail describing Llewellyn's likely motivations for creating the Bluebook's original incarnation).

${ }^{181}$ Lamie v. United States Trustee, 540 U.S. 526 (2004). 
session laws, that is, the laws passed by the Congress and signed by the President. ${ }^{182}$ "So if a law has been amended and there is a question about the new meaning, the consolidated text is relevant, but does not trump the session laws." 183 In Lamie, the Court refused to look at the session laws to resolve a facial ambiguity in the Bankruptcy Code as compiled in the Code: "The starting point in discerning congressional intent is the existing statutory text... and not the predecessor statutes." "184 The Court's statement elevating the Code over the session laws "was a casual, almost throwaway, line. 'Predecessor statutes': Put them with the committee reports and the dogs that didn't bark." 185 The Bluebook's requirement to cite the Code without resort to the session laws obscures the text and defeats the textual approach. This is not an isolated incident, as further examination of how legal citation obscures legislation will demonstrate.

\section{B. How Legal Citation Mistreats Legislative Evidence: A State- SPECIFIC CASE STUDY}

This importance of legal citation to the expert use of legislation has been noticed by others, although not widely so. The Florida State University Law Review developed the Florida Style Manual in direct response to the Bluebook's inexpert handling of legislation. In preparing its annual Review of Florida Legislation, the journal's editors found that "citation to many Florida-specific sources-particularly those generated by the Florida Legislature - would be rendered almost meaningless if [the] Bluebook [was] followed." 186 The Texas Tech Law Review published its Redbook in 1986 to fill the Greenbook's gaps with respect to legislative and administrative materials, ${ }^{187}$ while now mainly of historical value because of the lack of updates, ${ }^{188}$ it provides a useful window into those gaps.

Legal citation of legislation must be modified to ensure that lawyers and judges "interpret statutes with[] a better understanding of what the Constitution recognizes as legitimate - each house's rules and proceedings."189 To avoid a monumental task, ${ }^{190}$ I examine legal citation of legislation primarily using the highly distinctive jurisdiction of the State of Texas supplemented with examples from other states as is useful. This "limited consideration of the variations among

${ }^{182}$ Dorsey, supra note 152 , at 284-85.

${ }^{183}$ Id. at 292.

${ }^{184}$ Lamie, 540 U.S. at 534.

${ }^{185}$ Dorsey, supra note 152, at 292.

${ }^{186}$ FlORIDA STYLE MANUAL (Fla. State Law Review ed., 8th ed. 2019).

${ }^{187}$ Tex. Tech. L. Rev., Texas Legislative History and Admin. Agency Citation Guide (1st ed. 1986) [hereinafter TECH REDBOOK].

${ }^{188}$ A revision of this manual was promised in the early aughts. Volume 5 Executive Board Notes, 5 TEX. TECH. J. AdMIN. L. ix (2004). However, the first edition remains the only edition. E-mail from Donna B. Jones, Sec'y for Law Review, Tex. Tech. Univ. Sch. of Law (Feb. 16, 2016, 20:23 CST) (on file with author).

${ }^{189}$ NOURSE, MisREADING LAW, supra note 21, at 181.

${ }^{190}$ See Briffault, supra note 32, at 24 ("[W]ith Congress, the fifty states, and thousands of county and municipal legislatures to consider, a comprehensive analysis is well beyond my individual capacity."). 
state ... legislatures aids the analysis of ... the legislative process" $" 191$ and how it shapes legislation.

\section{Bills}

Let us start with the workhorse of the legislative process, the bill. Greenbook Rule 14.1.1 directs one to "[c]ite unenacted bills of the Texas Legislature by bill number, legislature number, session, and year," with appropriate designators for the session (regular or called) at which the bill was considered. ${ }^{192}$ Thus, we get this form:

Tex. H.B. 1578, 78th Leg., R.S. (2003).

The Bluebook requires and conveys similar information:

H.R. 1578, 78th Leg., Reg. Sess. (Tex. 2003). ${ }^{193}$

Let us look at the various elements of the Greenbook form and what it does, or does not, tell us about a bill.

First, why must we include the abbreviation "Tex."? Including "Tex." is likely superfluous in any type of practice in the state where citation to other states' legal materials is infrequent, but more so in the legislative context where citation to another state is so rare as to be non-existent. ${ }^{194}$ There are two important exceptions. First, it is required for citations to the Texas Constitution because of its coexistence with the U.S. Constitution. Second, it is required for citations in briefs and other material prepared for congressional committees and federal courts and agencies to avoid confusion with other state materials.

Unlike the Bluebook, the Greenbook follows Texas legislative practice and uses the abbreviations "H.B." and "S.B." followed by the bill number rather than importing the congressional forms of "H.R." and "S." to denote bills into state practice. ${ }^{195}$ (Unfortunately, the Greenbook does not continue this practice and uses the Bluebook congressional forms for resolutions.) ${ }^{196}$

${ }^{191} I d$.

${ }^{192}$ GREENBOOK 14th ed., supra note 1, at 66.

${ }^{193}$ BLUEBOOK 20th ed., supra note 1, at 135, 137.

${ }^{194}$ A practice approved by Justice Greenhill: "Where the brief is addressed to a Texas court, and it is obvious that the citation is to Acts of the Texas Legislature, the word "Texas" may be eliminated ...." Greenhill, Uniform Citations for Briefs, supra note 139, at 389. Even when discussing uniform acts and their consideration and application, an unadorned reference will ordinarily be taken to mean a reference to a Texas authority. In its survey of judges and lawyers to determine changes to the fourteenth edition, the Greenbook's editors retained the requirement for 'including 'Tex.' at the start of the citation [because it] serves as a useful cue to quickly differentiate between federal and Texas law" despite a near-even split in opinion as to its retention. MICHAEL J. DAus, Claire J. TAPSCOTT \& ANDREw P. VAN OSSElaER, 2018 TEXAS Rules OF Form SuRVEy RESUltS 27 (2018). Nothing certainly prevents a writer from including "Tex." if necessary to avoid confusion, but it seems very unnecessary.

${ }^{195}$ BLUEBOOK 20th ed., supra note 1, at 136, 139.

${ }^{196}$ Compare GREENBOOK 14th ed., supra note 1, at 67, with BLUEBOOK 20th ed., supra note 1, at 136. These abbreviations are Bluebook inventions and do not reflect those used by the Congress to denominate 
What the Greenbook rule ignores is that there may be-and likely areseveral versions of an unenacted bill: the bill as introduced; as reported from committee; as passed to engrossment; as finally passed ${ }^{197}$ in the house of origin; as reported by a committee of the other chamber; as amended by the other chamber; as finally passed by the other chamber; and as reported by a conference committee. ${ }^{198}$ Although enacted bills receive a session law chapter number (as discussed below), there is a delay in the chaptering process, and it is sometimes necessary to refer to the final version signed by the Governor. The Greenbook forms do not give the reader any idea of which version, if any, the writer consulted; especially in compiling or detailing a bill's legislative history, this information is key to both understanding the evolution of a measure and retrieving related information. ${ }^{199}$

For example, in discussing the effects of a truancy reform bill, Stephen Gilmore states the revenue gain to state government of aggressive truancy law enforcement, and cites "Fiscal Note, Tex. H.B. 2398, 84th Leg., R.S. (2015)."200 However, there are seven versions of the fiscal note for the bill, three of which state there is no fiscal implication to state government. ${ }^{201}$ While it might be inferred that the fiscal note referred to is the one prepared for the enrolled bill, the bill was significantly amended throughout the process, and that inference is not readily evident from the text.

The Tech Redbook recognized this need and sought to provide forms for several of these stages. Most bills that make it to the floor for consideration are committee substitutes. Using the Tech Redbook form, then, we would get:

Committee Substitute for H.B. 1578, Texas House of Reps., 78th Leg., Regular Sess. (2003).

What the Tech Redbook overlooks is that there can be two committee substitutes for a bill, one in the originating house and one in the reviewing house. It is common for each house's committees to report substitute bills, and the text is often divergent from the referred bill. Ordinarily, this version of a bill is referred to as, for example, "C.S.H.B. 10" or "C.S.S.B. 10," and that is the form at the top of the bill printing. Both the author and the reader need to know which committee substitute is being cited.

resolutions. Paul Axel-Lute, Legal Citation Form: Theory and Practice, 75 L. LIBR. J. 148, 156 (1982).

197 "Finally passed" is a term of art in the Texas Legislature to signify when one house has completed all states of consideration and sent a measure to the other house for consideration. E.g., TEX. H.R. RULE 8, § 19 (1999), TEX. H.R. 5, 76th Leg., R.S., 1999 H.J. OF TEX. 105 (providing that a "resolution to recall a bill from the senate shall be in order if a motion to reconsider the vote by which the bill finally passed has been [properly] made and adopted").

198 Again, this oversight is likely attributable to a similar oversight by the Bluebook. Axel-Lute, supra note 196 , at 155 .

${ }^{199}$ See NOURSE, MiSREADING LAW, supra note 21, at 157 (discussing that reverse engineering of the final text's development is “[t]he only real way to make sense of [the legislature's] decisions").

${ }^{200}$ Steven E. Gilmore, Education and its Discontents: The Decriminalization of Truancy and the Schoolto-Prison Pipeline in Texas, 18 SchOLAR 229, 240 (2016).

${ }^{201}$ Legis. Bill File, TEX. H.B. 2398, 84th Legis., R.S. (2015). 
The Tech Redbook also created a form for companion bills: ${ }^{202}$

Companion Bill for H.B. 1578, S.B. 266, 78th Leg., Regular Sess. (2003).

This form suggests an unwarranted importance for companion bills. Companion status is frequently misunderstood by participants as conferring a special status under the rules, especially the rule that permits the substitution of substantially similar bills from the other chamber during floor consideration. ${ }^{203}$ This rule speeds the process by moving the bill closest to the finish line in the legislative process. ${ }^{204}$ Many believe that the rule only applies to companion bills, but it applies broadly to any bill on the "same subject" (in the House) ${ }^{205}$ or "of the same general tenor" (in the Senate). ${ }^{206}$

Consider this example: a House bill regulating fireworks in certain counties has been placed on the House calendar, and a Senate bill that is substantially the same (but not identical) has been reported favorably by a House committee and is awaiting scheduling for the floor. When the House reaches the House bill on its calendar, the rule permits the Speaker to lay out the Senate bill instead because both bills are eligible for second reading consideration. ${ }^{207}$ A companion bill may be narrowed or enlarged so that it is no longer substantially similar when it catches up to the other companion. While the companion designation may be helpful in identifying bills on the same subject, it is not conclusive and might be misleading.

The Greenbook also does not indicate how one makes pinpoint citations to a bill's provisions, leading authors to omit them with unsatisfactory results. For example, Gilmore writes that "[t]he offense known as 'Failure to Attend School' has now been repealed, and all cross-references to former Education Code $\S 25.094$ have been stricken from the books" and then cites the entire forty-four-section bill, which covers thirty-three pages in the session laws, without any pinpoint citations. ${ }^{208}$ The bill expressly repealed the offense in section forty-one; it struck references to the repealed section in thirteen other sections. ${ }^{209}$ In a bill of any length, pinpoint citations are critical.

However, a bill's pagination does not show up on the HTML or Word versions of bills available online; one must access the PDF version online to view the correct page and line numbering. The general appropriations bill uses a unique "bill

\footnotetext{
${ }^{202}$ A companion bill is "[a] bill filed in one chamber that is identical or very similar to a bill filed in the opposite chamber.” TEX. LEGIS. COUNC., LEgISLATIVE GlOSSARY 4 (85th Legis. ed. 2017).

${ }^{203}$ TEX. H. Rule 6, § 10, TEX. H.R. 4, 86th Leg., R.S., 2019 H.J. OF TEX. 50, 109-10; TEX. S. Rule 7.14, TEX. S.R. 5, 2019 S.J. OF TEX. 19, 19, reprinted in Rules of the Senate, TEXAS LEGISLATIVE MANUAL 61.

${ }^{204}$ TeXas Legislative MANUAL, 38th Leg., R.S. 201-02 (1923).

205 TEX. H. RulE 6, § 10, TEX. H.R. 4, 86th Leg., R.S., 2019 H.J. OF TEX. 50, 109-10.

${ }^{206}$ S.J. OF TEX., 38th Leg., R.S. 470 (1923).

${ }^{207}$ See TEXAS HOUSE PRACTICE, supra note 167, at 501.

${ }^{208}$ Gilmore, supra note 200, at 240.

${ }^{209}$ Act of May 30, 2015, 84th Leg., R.S., ch. 935, § 41(2), 2015 Tex. Gen. Laws 3224, 3255 (repealing Educ. Code $\S 25.094) ; \S \S 8,9,11,12,13,14,17,29,30,32,33,34,36,2015$ Tex. Gen. Laws at 3227-30, 3231$32,3233,3250-52$.
} 
pattern" layout describing strategic goals, sources of funds, and other information necessary to understand or recapitulate the items of appropriation being made. The appropriate pinpoint citation, then, depends on the bill and version used.

Moreover, why must one specify that a bill was considered in a regular session? The Legislature is constitutionally required to hold a regular session of not more than 140 days every two years. ${ }^{210}$ For legislative materials between 1845 and 1876, the Greenbook declares that one "should simply omit the session designation" for those legislatures that only held the regular session; ${ }^{211}$ that ought to be sufficient for modern legislatures. ${ }^{212}$ The better practice is to designate the session only when one is dealing with extraordinary sessions, colloquially termed "special sessions" and designated for citation purposes as "called sessions." 13

Considering the foregoing, we can see that a more expressive citation that permits lawyers and judges to discuss a precise stage in the legislative process is, for example:

C.S.S.B. 266 (H. Comm. Rpt.) $\S 8$ [or at 10 or at 10:13-11:5], 78th

Legis. (May 21, 2003) [(companion to H.B. 1578)].

This example citation prioritizes the most important item of information: this bill passed the Senate, and a committee substitute for the engrossed bill was reported out of a House committee. One can easily see what version needs locating. It includes a pinpoint citation to the bill portion supporting an argument and permits one to choose an appropriate pinpoint cite: section, page, or page and line numbers. This form indicates the correct session with minimum distraction and permits, but does not require, the addition of a helpful parenthetical. It provides more information without being considerably longer than the Greenbook form. Most importantly, it aids in discussing both the procedural history and substantive contents of legislation.

\section{Resolutions}

The Greenbook does not handle resolutions much better. The Greenbook speaks of "enacted resolutions." 214 This error seems directly attributable to the Bluebook, which speaks of "unenacted resolutions." 215 In Texas legislative practice,

\footnotetext{
${ }^{210}$ TEX. CONST. art. III, §§ 5(a), 24(b); see also TEX. Gov’T CODE ANN. $\$ 301.001$ (West 2013).

${ }^{211}$ GREENBOOK 14th ed., supra note 1, at 118.

${ }^{212}$ Justice Greenhill urged that where there was only a Regular Session, the "R.S." may be omitted." Uniform Citations for Briefs, supra note 139, at 389.

${ }^{213}$ The phrase "called session" is derived from the reference to the Governor's proclamation as the "call" of the session, in turn derived from the Texas Constitution's reference to "the proclamation of the Governor calling [a special] session." TEX. CONST. art. III, $\S 40$. The phrase displaced that of "extra session" sometime between 1879 and 1884. Compare, e.g., H.J. OF TEX., 16th Leg., 1st C.S., tit. pg. (1879), with H.J. OF TEX., 18th Leg., 1st C.S., tit. pg. (1884).

${ }^{214}$ GREENBOOK 14th ed., supra note 1, at 67.

${ }^{215}$ The U.S. Constitution does not explicitly require that laws be enacted by bill. For example, it requires that "[n]o Money shall be drawn from the Treasury, but in Consequence of Appropriations made by law ...."
} 
a resolution is adopted, not enacted. ${ }^{216}$ This is because resolutions are not law in Texas; only bills may enact law. ${ }^{217}$ Thus, resolutions do not have an enacting clause. ${ }^{218}$ Similarly, because they are not law, resolutions cannot be "codified"; the Greenbook instructs that "if codified, a resolution should be cited as a statute"219 simply makes no sense. If the Greenbook is referring to amendments to the Texas Constitution proposed by joint resolutions, when amendments are approved by the voters, they become part of the constitution itself and should be cited under chapter nine, "Current Constitution." Finally, just as for a bill, there may be several versions of a resolution before it passes or fails; thus, Greenbook forms for resolutions suffer from many of the same defects as those discussed above for bills.

\section{Amendments}

Turning to amendments to measures, the Greenbook simply does not address them. Amendments directly shape the final text and may take the bill beyond an original concept; they form part of the "better pedigree" of determining the meaning of the final text. ${ }^{220}$ The Texas amendment tree is straightforward; however, the sequencing of amendments under the tree must be noted to aid in understanding the proceedings. ${ }^{221}$ The key actions on amendments are whether a house adopts them or disposes of them through parliamentary means, i.e., a motion to table or a point of order. There is a difference between the two methods. Adoption of a motion to table $\mathrm{e}^{222}$ an amendment is that house's final and adverse disposition of that amendment, rather than a simple refusal to consider it at that time. ${ }^{223}$ If an amendment

U.S. CONST. art I, § 9, cl. 7. The Congress has made appropriations through joint resolution. See, e.g., Act of Oct. 18, 1986, Pub. L. No. 99-500, 100 Stat. 1783 (1986).

${ }^{216}$ See, e.g., TEX. H. RULE 9, § 1(c), TEX. H.R. 4, 86th Leg., R.S., 2019 H.J. OF TEX. 50, 132 (stating that "[a] joint resolution [proposing a constitutional amendment] shall be adopted on any reading after the first if it receives" the necessary supermajority and that "it shall fail of adoption[]" if it does not receive the necessary supermajority on its third reading); H.J. OF TEX., 1st Cong., R.S., 80 (1838) (recording that "a joint resolution ... was called up and read a second time ... Mr. White moved that the resolution be adopted; and the questions being taken thereon, was decided in the affirmative").

${ }^{217}$ TEX. CONST. art. III, § 30 ("No law shall be passed, except by bill . . ..”); Mosheim v. Rollins, 79 S.W.2d 672, 674-75 (Tex. Civ. App. 1935).

${ }^{218}$ Tex. H.R.J. Res. 4, 71st Leg., R.S., 1989 Gen. Laws 6424 (showing the resolving clause for a joint resolution proposing an amendment to Texas Constitution); Tex. H.R.J. Res. 6, 71st Leg., R.S., 1989 Tex. Gen. Laws 6424 (showing the resolving clause for a joint resolution ratifying the Twenty-Seventh Amendment to the U.S. Constitution).

${ }^{219}$ GREENBOOK 14th ed., supra note 1, at 67.

${ }^{220}$ Nourse, Decision Theory, supra note 38, at 97. As noted, adoption of an amendment deleting text in a bill is legislative evidence of the deleted language's rejection. Smith v. Baldwin, 611 S.W.2d 611, 616-17 (Tex. 1980). However, there is "no controlling significance to the Legislature's failure to enact [a] proposed amendment." Entergy Gulf States, Inc. v. Summers, 282 S.W.3d 433, 443 (Tex. 2009) (quoting Tex. Emp't Comm'n v. Holberg, 440 S.W.2d 38, 42 (Tex. 1969)).

${ }^{221}$ The Tech Redbook attempted to fill the gap, but the forms did not address the sequencing concern. See TECH REDBOOK, supra note 187.

${ }^{222}$ The motion to table can be applied to any pending legislative business. See TeX. H. RulE 7, § 12, TeX. H.R. 4, 86th Leg., R.S., 2019 H.J. OF TEX. 50, 118

${ }^{223}$ E.g., id. (providing that an adopted motion to table "shall have the effect of killing the bill, resolution, amendment, or other immediate proposition to which it was applied[]"). 
is tabled or not, that is a material fact that should be noted under any system of legal citation.

A point of order does not represent a decision on the merits, but only a decision as to whether the amendment meets certain substantive and procedural requirements, including form, timely filing, calendar rules, and germaneness. The question of germaneness is often a "theological" question, ${ }^{224}$ and it should be noted if the amendment was ruled out on those grounds to aid in better understanding of the proceedings, especially in any challenge under the Texas Constitution's germaneness rule. While the other provisions governing amendments are more technical, points of order dispositions should be noted to avoid imputing any judgment on the merits.

\section{Procedural History and Explanatory Notations}

The Greenbook does not prescribe procedural history or explanatory notations for legislation. The Texas Senate's three-fifths rule requires a supermajority to bring a bill to the floor under almost all circumstances. Failure of a suspension vote is significant because it shows that the Senate effectively rejected the bill. Thus, the notation "suspension of the regular order failed" should be inserted after the citation information for the bill:

S.B. 342 (S. Comm. Rpt.) (78th Leg.), suspension of the regular order failed, 78 S.J. Reg. 964 (2003).

Similarly, adoption of the motion to strike the enacting clause shows that the body affirmatively voted to kill the bill:

H.J.R. 35 (H. Comm. Rpt.), enacting clause stricken, 79 H.J. Reg. $1658,1675-1676(2005)$.

As discussed above, amendments can be killed in one of a few ways: through a straight up or down vote on their adoption; by tabling them; or by a successful point of order that the amendment does not comply with all procedural rules. The fact of any of these is material to understanding the action taken on the proposal. Thus, we could have the following:

H. Fl. Amend. No. 1 by Hartnett, et al., to C.S.S.B. 266 (H. Comm. Rpt.), withdrawn, 78 H. Jour. 3884 (May 25, 2003).

H. Fl. Amend. No. 3 by Hill to H. Fl. Amend. No. 2 by Gallego to C.S.S.B. 266 (H. Comm. Rpt.), failed of adoption on record vote, 78 H. Jour. 3885 (May 25, 2003).

224 George D. Braden et AL., The Constitution of the StAte of TeXas: An AnNOtATED AND COMPARATIVE ANALYSIS 162 (1977). 
A special case is presented when dealing with the second chamber's amendments to the engrossed text received from the first chamber. If the engrossed text is a House bill, the Senate's changes are termed "Senate amendments"; although stated in the plural, the set of amendment documents is considered a single, indivisible amendment for purpose of concurring or going to conference. ${ }^{225}$ This, too, must be properly indicated like so:

S. Amends. to H.B. 2098 (Engr.), concurrence refused and conference requested, 85 H. Jour. 4879 (May 25, 2017).

S. Amends to H.B. 1729 (Engr.), concurrence on record vote, $85 \mathrm{H}$. Jour. 3978 (May 20, 2017).

The importance of procedural history when citing legislation is not isolated to Texas, and a couple of examples from other states show this. In New York, the Senate majority leader may "star" a bill appearing on the calendar, which suspends all further action on its passage. ${ }^{226}$ Once affixed, only the majority leader may remove the designation, and action may resume not earlier than the day after its removal. ${ }^{227}$ While starring may be used to buy time to address "technically defective" legislation, ${ }^{228}$ it is "[t]he most absolute, undemocratic procedure that can possibly exist" because it also permits a majority leader to delay or kill legislation that is likely supported by a chamber majority. ${ }^{229}$ Just as with a failure to suspend the rules in Texas, starring is a significant practice because it represents an adverse action on a bill that should be reflected in the bill's citation information:

(2020 NY Senate Bill S9566, starred, S. Calen. for May 30, 2020, unstarred, S. Calen. for Aug. 2, 2020).

In Massachusetts, a single member may block consideration of bills considered during "informal sessions" held to circumvent session-ending deadlines and during which unanimous consent is required to pass any legislation. ${ }^{230}$ Again, this is an adverse action that is necessary to understand enactment history, especially

\footnotetext{
(1959).

${ }^{225}$ E.g., Rules of the House of Representatives, in TEX. LegisLative MANUAL: 56th Leg., R.S., 355

${ }^{226}$ Jeremy M. Creelan \& Laura M. Moulton, The New York State Legislative Process: An EVALUATION AND BLUEPRINT FOR REFORM 21-22 (2004).

${ }^{227} \mathrm{Id}$. at 22; JOSEPH F. ZiMMERMAN, THE GOVERNMENT AND POLITICS OF NEW YORK STATE 108, 110 (2d ed. 2008)

${ }^{228}$ One study found that roughly one-half of the stars were requested by bill sponsors. John J. Pitney, Jr., Leaders and Rules in the New York State Senate, 7 LEGIS. STUD. Q. 491, 495 (1982).

${ }^{229}$ CREELAN \& MOULTON, supra note 226, at 22.

${ }^{230}$ Steven T. James, Government by Consensus-Restrictions on Formal Business in the Massachusetts Legislature Inspire Innovative Ways to Govern, 13 J. AM. SOC'Y LEGIS. CLERKS \& SEC'YS 69, 74 (2007).
} 
if any argument is later made that the legislature "rejected" an attempt to clarify an existing statute:

2020 H. 3400, unanimous consent refused in informal session, 2020

H. Jour. 1160 (Nov. 30, 2020).

\section{THE WAY ForWARD: CITATION MANUALS FOR LEGISLATION}

Because of the case law-centered view of legal practice, forms for legislative materials are largely unsettled, which provides room for substantial improvements untethered from the Bluebook. ${ }^{231}$ Returning to Texas, I would propose an Orangebook ${ }^{232}$ to serve as that state's manual of legal citation for legislation. It would analyze the jurisdiction-specific ways in which the Texas legislative process operates to shape the Legislature's final decision and specify the significant information lawyers and judges need when pointing to the relevant legislative evidence in context needed to explain those decisions to each other. It would address the unique methods used by the Texas Legislature that differ from Congress and note why those unique methods matter in understanding what happened during the enactment process. In the familiar context of a citation manual, an Orangebook will enable expert reasoning from legislation by common-law lawyers.

For Texas legislation, then, the Orangebook will provide Texas lawyers with a straightforward citation system that aids expert legal thought concerning legislation and reflects the peculiarities of the state's unique lawmaking process. Taking a lessprescriptive approach to legislative citation is inadequate. There simply is too much information that needs to be provided to leave it to chance, and lawyers and judges

${ }^{231}$ See Bryan A. Garner, An Uninformed System of Citation: The Maroonbook Blues, 1 SCRIBES J. LEGAL WRITING 192, 192 (1990) (urging adherence to settled citation forms). Non-lawyers participating in the legislative process lack the same attachment to legal citation practice yet also need a workable method of citing legislation, for which non-legal systems are also unsatisfactory. E.g., Legal Documents, in KAREN PATRIAS, Citing Medicine: The NLM StYle Guide for Authors, Editors, AND Publishers (Daniel L. Wendling ed., $2 d$ ed. 2009) (making "no attempt ... to force references to legal materials such as public laws and hearings into a [non-legal] format"). The Orangebook permits non-lawyers to engage with lawyers and judges on equal terms.

${ }^{232}$ Now seems the best time as any to claim this color for a citation manual. This complements its use by the Food and Drug Administration's use of the term to describe its directory of approved drugs and usessomewhat ironic seems apt, given the anxiety over citation. See Orange Book: Approved Drug Products with Therapeutic Equivalence Evaluations, U.S. FOOD \& DRUG ADMIN., https://perma.cc/VZN9-VKCM (last visited April 24, 2018). The London County Council's 1893 report on assessments according to benefits was colloquially referred to as the Orange Book. See EDWIN R.A. SELIGMan, ESSAYS IN TAXATION 343 n.1, 349 n.1 (1895). Pepperdine University School of Law issues an Orange Book, an orientation guide for first-year law students, the color being one of two university colors, the other blue. PePperdine Univ. SCH. OF LAW, The ORANGE BOOK 2014 (2017), https://perma.cc/TK78-L76L; University Colors, PEPPERDINE UnIV., https://perma.cc/8RCS-WKWD (last visited Apr. 24, 2018). None of these uses conflict with the use of the term here. 
do not yet have enough experience reading legislation in light of legislative procedure. $^{233}$

In Appendix A, I set out the topics that would be addressed by the Orangebook. In Appendix B, I set out the text of a proposed citation rule for bills that is a comprehensive approach to the problems presented in Part 2.B, and the appended rule explains the rationales for the suggested citation forms. The Orangebook would "correct[] most of the [Greenbook's] faults that I have discussed in this [Article] and[, I hope,] introduce[] no new ones."234 It would ensure that the "the reader [is given all] valuable information" 235 to expertly reason about the products of the legislative process. And, as we have seen, the Bluebook and Greenbook have ceded this area in favor of their common-law regimes; just as the Greenbook displaced the Bluebook in the citation of Texas case law, it is expected that the Orangebook would do the same to the Greenbook for Texas legislation. And it achieves two important goals.

At a minimum, the Orangebook should aid in improving lawyers' thinking about legislation by according these materials the same care and consideration accorded to case law regardless of interpretative theory. It faithfully expresses the types of authorities and process-dependent reasoning used by lawyers practicing in the legislative branch. These improvements also recognize that legislative materials are legal authorities, equal to cases, to be used in legal reasoning. It provides "a reliable system of citing" legislation to permit its "attentive and meticulous deployment" in legal argument about the legislature's decision embodied in the final text of its statutes and resolutions. ${ }^{236}$ The Orangebook will greatly enhance the ability of lawyers and judges to "understand the nuances of [legislation;] to cite it correctly and thoughtfully" and to do so in a "readily available, comprehensible form" 237 that mirrors the forms used for cases and common-law authorities. This further aids the Orangebook's acceptance by lawyers and judges because it relies on the familiar patterns of legal reasoning embodied in traditional legal citation. ${ }^{238}$

More importantly, the Orangebook permits lawyers and judges to implement Nourse's legislative decision theory when interpreting statutes. As we saw in Part II, using legislative decision theory to interpret statutes avoids the counter-majoritarian problems of current statutory interpretation theories that "allow those who lost the fight in Congress to win in the courts." 239 However, as we saw in reviewing Jones and Fleming Foods, the theory cannot be properly implemented until legal citation permits lawyers and judges to locate, identify, understand, and explain the sources and nature of the group-authorized legislative evidence that provides the necessary context to understand what the legislature did in enacting a statute. The Orangebook

${ }^{233}$ See Garner, supra note 231, at 194-95 (describing the problems with "frequent grants of discretion" in legal citation as expressed in the University of Chicago Law Review's Maroonbook).

${ }^{234}$ See Richard A. Posner, Goodbye to the Bluebook, 53 U. CHI. L. REV. 1343, 1351-52 (1986).

${ }^{235}$ See id. at 1352 .

${ }^{236}$ See Shapiro \& Krishnaswami, supra note 126, at 1575.

${ }^{237}$ See Franklin, supra note 22, at 132.

${ }^{238}$ See supra Part I.C.

${ }^{239}$ NOURSE, MiSREADING LAW, supra note 21, at 34-63. 
permits expert reverse engineering of the statute to determine all relevant evidence of how the majority, at each stage of enactment, shaped the final text that both houses passed and presented to the executive. In short, use of the Orangebook should prevent recurring, substantial errors in statutory interpretation like those we saw in Jones and Fleming Foods.

\section{CONCLUSION}

Errors in statutory interpretation are directly attributable to legal citation's failure to adequately provide for understanding or expressing the legislative procedures adopted to guide the legislature's decisions in enacting statutes. Providing a comprehensive method of citation for legislative materials that accounts correctly for legislation and the procedural context of its development aids better statutory interpretation that is faithful to those group decisions. Better legal citation of legislation helps a legal reader evaluate the actions required or taken at each stage of the legislative process to determine what the legislature decided by providing citation forms to permit lawyers to intelligently and fluently discuss the legislative process when interpreting statutes.

While the Orangebook citation manual sketched in this Article is specific to Texas, it sets an example for other regional jurisdictions to develop sophisticated rules of legal citation expressing their particular lawmaking processes - and even for the Bluebook to do the same for the Congress. The Orangebook - and others like itmakes legislation count when reasoning legally in the age of statutes. ${ }^{240}$

\footnotetext{
${ }^{240}$ See Schauer, Authority and Authorities, schauer note 25, at 1960-61.
} 
I. Constitutions

A. Constitutional Provisions Currently in Force

B. Constitutional Provisions Approved But Not Yet Effective

C. Constitutional Provisions No Longer in Force

D. Constitutional Convention Ordinances

II. Statutes

A. Codified Statutes

B. Uncodified Statutes

C. Statutory Compilations

D. Enacted Appropriations Bills

III. Session Laws

A. Session Laws, Generally

B. Session Laws, Special Cases

IV. Bills

A. Bills, Generally

B. Bills, Appropriations

C. Bills, Committee Amendments

D. Bills, Floor Amendments

E. Bills, Amendments Between the Two Houses

V. Joint Resolutions

A. Joint Resolutions, Generally

VI. Concurrent and Simple Resolutions

A. Concurrent Resolutions

B. Simple Resolutions

VII. Legislative Journals, Debates, and Remarks

A. Journals, Generally

B. Journals, Remarks and Debate

C. Other Debates and Remarks, House

D. Other Debates and Remarks, Senate

E. Third-Party Transcripts

VIII. Legislative Rules

A. Rules of Procedure

B. Internal Rules

C. Calendar Rules

D. Legislative Precedents

E. Secondary Authorities

F. Explanatory Notes and Comments

IX. Calendars and Lists of Business

A. House Calendars and Lists of Items Eligible for Consideration

B. Senate Regular Order of Business and Senate Agenda

X. Legislative Documents 

A. Analyses of Legislation
B. Bill File
C. Fiscal Notes
D. Impact Statements
E. Revisor's Reports

XI. Committee Proceedings
A. Committee Minutes and Meeting Notices

B. Committee Hearings and Testimony

XII. Texas Legislature Online

XIII. Executive Material: The Governor
A. Veto Messages
B. Other Messages to the Legislature
C. Signature Statements
D. Executive Orders
E. Proclamations
F. Other Materials 


\section{APPENDix B: SAMPle CitATION RUle FOR BiLls}

\section{Rule 7. BILLS AND AMENDMENTS}

\section{Rule 7.1 Bills, Generally}

Greenbook Rule 14.1.1

The standard citation to a bill includes the type of bill, the bill number, the bill version, a pinpoint reference (if any), the legislature number, session type (if necessary), and the date of the document. House bills are designated "H.B." and Senate bills are designated "S.B." You do not need to designate regular sessions as the Legislature is constitutionally required to hold a biennial regular session. For example:

H.B. 525 (Filed) at 1 [or $\S 1]$, 79th Legis. (Jan. 24, 2005).

There are many versions of a bill as it makes its way through the legislative process, and the appropriate version must be indicated unless the citation context otherwise makes the bill version clear. Those exceptions are noted under the appropriate citation rule. The major bill versions are:

Filed The version of the bill as filed and introduced in its chamber of origin.

H. or $\mathrm{S}$. The version of the bill as reported from a committee in Comm. Rpt. either chamber. If the version is a committee substitute, indicate that separately as noted below.

Engr. The version of the bill as approved after the major amendment stage of $2 \mathrm{~d}$ reading.

Conf. Comm. The version of the bill proposed by a conference Rpt. committee after different versions of the bill were approved by each chamber.

Enr. The version of the bill as finally approved in identical text by each chamber.

Under House and Senate rules, a committee may report a complete substitute in lieu of the referred bill and the committee substitute then becomes the text considered on second reading. Because a committee in either chamber may report a substitute for a bill from the other chamber, note both the fact of the substitution and the chamber in which it occurred. Cite a committee substitute as follows:

C.S.H.B. 274 (H. Comm. Rpt.) § 1, 85th Legis. (Apr. 17, 2017). 
Committee reports are required to be printed and distributed to the full chamber. At times, a chamber may order that a committee report on a noncontroversial bill, such as a non-substantive statutory codification, not be printed. Note when a chamber orders a bill not printed:

C.S.H.B. 274 (H. Comm. Rpt.) § 1, 85th Legis. (Apr. 17, 2017) (ordered not printed).

If a bill has a short title, you may begin the citation with it. Do not confuse the short title of a bill with either the bill's caption describing its subject (i.e., "relating to the minimum wage") or the bill's assignment of a short title to a proposed portion of a code or statue (i.e., the bill designates a proposed new chapter of the Occupations Code as the Full Employment Act). For example:

Minimum Wage Amendments of 1997, H.B. 334 (Filed) § 2, 75th Legis. (Dec. 12, 1996).

If the bill designates a new proposed portion of a code or statute with a short title, you may indicate that parenthetically:

S.B. 1193 (H. Comm. Rpt.) § 1, 84th Legis. (May 10, 2017) (proposing the Texas Revised Uniform Fiduciary Access to Digital Assets Act as ch. 2001, Estates Code).

If citing to line numbers in a bill, rather than to sections, use a semicolon to separate the line number from the page number:

H.B. 525 (Filed) at 1:28, 79th Legis. (Jan. 24, 2005).

Enacted bills are cited as statutes under Rule 5 or as session laws under Rule 6. An exception is when discussing the legislative history and it is necessary to cite the enrolled bill; for example, when the bill has not yet been approved or vetoed by the Governor:

H.B. 525 (Enr.) at 5, 79th Legis. (May 20, 2005).

If a bill is vetoed, note that fact as subsequent history:

H.B. 2153 (Enr.), vetoed, 66 H. Jour. 3272-3273 (1979).

H.B. 32 (Enr.), vetoed, 28 Tex. Reg. 5691 (July 25, 2003).

H.B. 1776 (Enr.), vetoed, Gov. Ann W. Richards, Veto Message, 72d

Legis. (June 3, 1993).

If the veto is overridden, indicate that fact as subsequent history: 
H.B. 2153 (Enr.), veto overridden, 66 H. Jour. 3276 and 66 S. Jour. 1431 (1979).

A bill's subsequent history must be indicated for certain negative actions that effectively kill, or significantly impede further progress of, a bill:

$\begin{array}{ll}\begin{array}{l}\text { enacting } \\ \text { clause } \\ \text { stricken } \\ \text { point of } \\ \text { order } \\ \text { sustained } \\ \text { against }\end{array} & \begin{array}{l}\text { The motion to strike the enacting clause was adopted, which } \\ \text { affirmatively kills the bill. }\end{array} \\ & \begin{array}{l}\text { Further consideration of the bill was precluded by a successful } \\ \text { point of order. Unless describing the legislative history or the } \\ \text { doctrinal contours of a legislative rule, it is not necessary to note } \\ \text { points of order that were not sustained. A parenthetical noting } \\ \text { the section of the rules under which the point of order was } \\ \text { brought is useful. } \\ \text { The motion to reconsider a vote by which the bill was passed to } \\ \text { engrossment or finally passed. Indicate the vote that was }\end{array} \\ & \begin{array}{l}\text { reconsidered. Unless essential to describing the legislative } \\ \text { history, it is not necessary to note failures to reconsider. }\end{array} \\ \text { suspension } \\ \begin{array}{l}\text { of the } \\ \text { regular } \\ \text { order failed }\end{array}\end{array} \quad \begin{aligned} & \text { The Senate refused to consider the bill. The motion to suspend } \\ & \text { the regular order may be renewed; if passed at a later time, there } \\ & \text { is no need to include the prior rejection unless describing the } \\ & \text { legislative history or the doctrinal contours of a legislative rule. }\end{aligned}$

Rule 7.2 Bills, Appropriations

No Greenbook Rule

Unenacted appropriations bills may include a citation to specific appropriations or riders as under Rule 5.4:

Item B.1.1 (Plant Health \& Seed Quality, Agric. Dept.), S.B. 1

(Engr.) at VI-2, 79th Legis. (Mar. 23, 2005).

Rider 21 (Tex. Wine Mktg. Assistance Program, Agric. Dept.), S.B.

1 (Conf. Comm. Rpt.) at VI-6, 79th Legis. (May 28, 2005).

\section{Rule 7.3 Bills, Committee Amendments}

\section{No Greenbook Rule}

For minor technical and clarifying amendments to referred bills, committees may recommend discrete amendments instead of reporting a complete committee substitute. Any committee amendment must be offered by an individual member on 
the floor before it may be considered. Cite committee amendments if discussing a bill before its second reading consideration or if discussing unoffered amendments.

S. Jud. Comm. Amend. No. 1 to H.B. 930 (S. Comm. Rpt.) at 1, 80th Legis. (May 7, 2007).

\section{Rule 7.4 Bills, Floor Amendments \\ No Greenbook Rule}

Floor amendments may be offered to a bill on its second or third readings. Amendments are classed according to the order in which they are offered; up to three types of amendments may be pending at any one time: an amendment, an amendment to the amendment, and a substitute for the amendment to the amendment. The appropriate class must be indicated, and its procedural posture should be indicated if needed for clarification. The text of each amendment is printed in, and must be cited to, the journal; omit the session designation as that information is conveyed by the journal citation. You should indicate the procedural posture of the amendment as appropriate.

H. Fl. Amend. No. 3 by Hill to H. Fl. Amend. No. 2 by Gallego to C.S.S.B. 266 (H. Comm. Rpt.), motion to table failed on record vote, 78 H. Jour. 3885 (May 25, 2003).

H. Fl. Amend. No. 3 by Hill to H. Fl. Amend. No. 2 by Gallego to C.S.S.B. 266 (H. Comm. Rpt.), failed of adoption on record vote, 78 H. Jour. 3886 (May 25, 2003).

H. Fl. Amend. No. 2 by Gallego to C.S.S.B. 266 (H. Comm. Rpt.), adopted [on record vote], 78 H. Jour. 3886 (May 25, 2003).

H. Fl. Amend. No. 2 by Morrison to S.B. 4 (3d Rdg.), adopted, 78 H. Jour. 4079 (May 26, 2003).

A main amendment may take the form of a complete substitute for the bill, in which all text after the enacting clause is stricken and replaced. That fact must be indicated:

H. Fl. Amend. No. 1 by Wolens to C.S.H.J.R. 31 (H. Comm. Rpt), 75 H. Jour. 2172-2177 (May 9, 1997) (complete floor substitute).

Once an amendment has been amended, indicate that fact in all subsequent discussions of that amendment: 

2001).

Procedural postures are indicated by the following phrases:

\begin{tabular}{|c|c|}
\hline adopted & The amendment was adopted. \\
\hline $\begin{array}{l}\text { failed of } \\
\text { adoption }\end{array}$ & The amendment affirmatively rejected by the chamber. \\
\hline $\begin{array}{l}\text { point of order } \\
\text { sustained } \\
\text { against }\end{array}$ & $\begin{array}{l}\text { Further consideration of the amendment was precluded } \\
\text { by a successful point of order. Unless describing the } \\
\text { legislative history or the doctrinal contours of a } \\
\text { legislative rule, it is not necessary to note points of order } \\
\text { that were not sustained. A parenthetical noting the } \\
\text { section of the rules under which the point of order was } \\
\text { brought is useful. }\end{array}$ \\
\hline reconsidered & $\begin{array}{l}\text { The motion to reconsider a vote on prior action on the } \\
\text { amendment was adopted. Unless essential to describing } \\
\text { the legislative history, it is not necessary to note failures } \\
\text { to reconsider. }\end{array}$ \\
\hline tabled & The amendment was tabled. \\
\hline $\begin{array}{l}\text { motion to table } \\
\text { failed }\end{array}$ & The amendment was not tabled. \\
\hline withdrawn & $\begin{array}{l}\text { The amendment was withdrawn, ordinarily because of } \\
\text { the threat of a point of order or to cure substantive } \\
\text { disagreement. }\end{array}$ \\
\hline
\end{tabular}

For any action on which a recorded vote was taken, add "on record vote" after the procedural phrase.

Rule 7.5 Bills, Amendments Between the Two Houses No Greenbook Rule

One house of the Legislature cannot directly amend a bill originating in the other, but instead adopts one or more separate amendments indicating the adopting house's preferred text. For example, an engrossed House bill is sent to the Senate and referred to a Senate committee. That committee reports a complete committee substitute, which is then amended one or more times on the Senate floor. Before final passage in the Senate, cite amendments under Rule 7.3-7.4. Example: 
S. Fl. Amend. No. 1 by Estes to C.S.H.B. 2533 (S. Comm.

Rpt.), adopted, 85 S. Jour. 2458 (May 22, 2017).

The engrossed bill is not altered to incorporate the text of these amendments, but is returned after final passage to the originating house with the adopting house's amendments separately attached. The originating house may concur in those amendments, and replace the text of the its bill, or refuse to concur and request a conference. Regardless of the number or type of the adopting house's amendments, they are considered as a single, indivisible document related to the engrossed bill after final passage in the second house. Example:

S. Amends. to H.B. 2533 (Engr.) at 1, 85th Legis. (May 22, 2017). 